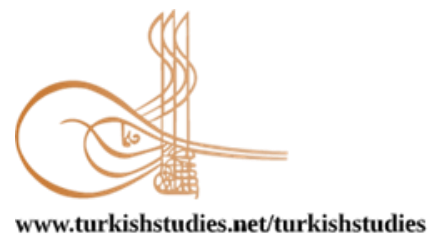

Turkish Studies

\title{
Covid-19 Pandemi Sürecinde Yapılan E-Ders Uygulamalarının Etkililiğinin Öğrencilerin Perspektifinden Değerlendirilmesi
}

\author{
Evaluation of the Effectiveness of E-Course Practices during the Covid-19 Pandemic from the \\ Students' Perspective
}

Ramazan Atasoy* - Celalettin Özden ${ }^{* *}$ - Dönay Nisa Kara***

\begin{abstract}
Covid-19 pandemic has deeply affected ongoing individual, social, public, and institutional actions and habits regarding communal life in many countries. One of the most affected public institutions has been educational institutions that have to change and transform the natural educational environment and methods rapidly. This study aims to reveal the perception of university students' satisfaction for the e-courses they received during the Covid-19 pandemic and the level of teacher innovativeness that predicts student satisfaction for e-learning. The study sample consists of 263 university students studying through e-courses in science and education faculties of a private university in the Turkish Republic of Northern Cyprus (TRNC) and selected by a simple random sampling method from different grade levels. The 'satisfaction scale for ecourse' and the teacher innovativeness dimension used in TALIS 2018 were used as data collection tools. The data were analyzed with SPSS 23 software program. Frequency, percentage, arithmetic mean, and standard deviation for descriptive statistics, t-test and one-way analysis of variance (One Way ANOVA) were used to test the differences between groups, and Pearson Correlation analysis and regression analysis were used to determine the relationships between variables in the research. Student satisfaction for e-courses is at a medium level, the lowest satisfaction is in the material dimension, and the highest is the studentteacher interaction and teacher innovativeness dimensions. It has been found that the interest, satisfaction, and motivation levels of male participants whose mothers received high school education or higher education are high for e-lesson activities for male participants according to gender. Female participants and Turkish group teaching department participants have been found to prefer face-to-face learning activities. Also, there are significant differences for computer department students according to the department they study, and on behalf of those who use the internet more for lecture purposes. Finally, a strong correlation has been found
\end{abstract}

\footnotetext{
*Dr., Milli Eğitim Bakanlığı (MEB)

Dr., Republic of Turkey Ministry of National Education

ORCID 0000-0002-9198-074X

atasoyramazan@gmail.com

** Dr., Milli Eğitim Bakanlığı (MEB)

Dr., Republic of Turkey Ministry of National Education

ORCID 0000-0003-3728-7781

cozden2001@gmail.com

*** Dr., Girne Amerikan Üniversitesi, Eğitim Fakültesi, Bilgisayar ve Öğretim Teknolojileri Öğretmenliği

Dr., Girne American University, Faculty of Education, Computer Education and Instructional Technology Teaching ORCID 0000-0001-2345-6789

donaykara@gau.edu.tr

Cite as/ Atıf: Atasoy, R., Özden, C. \& Kara, D. N. (2020). Covid-19 pandemi sürecinde yapılan E-ders uygulamalarının etkililiğinin öğrencilerin perspektifinden değerlendirilmesi. Turkish Studies, 15(6), 95-122. https://dx.doi.org/10.7827/TurkishStudies.44491

Received/Geliş: 24 June/Haziran 2020

Accepted/Kabul: 15 October/Ekim 2020

Copyright $(\mathrm{C}$ MDE, Turkey

Checked by plagiarism software

Published/Yayın: 20 October/Ekim 2020

CC BY-NC 4.0
} 
between e-course satisfaction and teacher innovativeness. It has been concluded that teacher innovativeness is a significant predictor of students' e-course satisfaction. Carefully planning, preparing, and implementing all processes of e-course practices that emphasize student satisfaction, especially develop teacher qualifications, and are recommended to increase student satisfaction in e-learning processes.

Structured Abstract: The Covid-19 virus's spreading rapidly worldwide has turned into a pandemic and threatens society's life. It has dramatically changed the operation process of educational organizations. The education systems of the countries with the Covid-19 pandemic, firstly stopped the education and training processes at all educational institutions as a precautionary measure, along with the expectation that the pandemic process will last as long as the whole world online e-course training processes were carried into practice instead of face-to-face education at universities in the Turkish Republic of Northern Cyprus (TRNC). However, this transition process could not be practiced at the same speed, at the same time, and with the same success in every university. Although e-learning has a long history, it has been narrowly practiced in universities in the TRNC and Turkey. However, e-learning practices, which stand out with the pandemic process and try to substitute the gap of face-to-face education, have placed on the list of universities as a training tool of technology and as a radical result of necessity. The prominence of e-learning practices with the pandemic effect has brought along problems of adaptation to this process and e-learning process for both students and lecturers in universities. Teacher innovativeness plays an essential role in the success of e-learning processes, and the satisfaction of students has been proved in the related literature (Cidral et al., 2018; Sun et al., 2008; Lwoga, 2014; Mtebe \& Raphael, 2018). Many activities could be practiced in face-to-face lessons to increase student motivation. Nevertheless, the situation is a little more complex, and different in online education. The usability of the system and acceptance of the student elearning is accepted as one of the basic requirements of the successful e-learning system as well as the usefulness of e-learning platforms (Almaiah, 2018) for the success of e-learning systems (Almaiah et al., 2020). E-learning platforms contribute to increasing students' level of learning and performance, facilitating the achievement of their goals by using less effort, and thus, achieving more effective and lasting knowledge, increasing students' satisfaction levels, developing a positive attitude for e-learning and reaching high motivation (Cidral et al., 2018; Ghazal et al., 2018; Lwoga, 2014). E-learning systems are internet-based and innovative learning platforms that have many advantages and disadvantages. They are online and/or offline educational environments where digital technologies are used in all levels of the education system, which are evaluated within the scope of education 4.0. These environments are widely used for education in Turkey and the TRNC at all levels of the organization and are carried out face to face with a supportive educational environment of formats. With the Covid-19 pandemic, e-learning has entered the center of our education life. The COVID-19 pandemic caused radical changes in the habits of the community and made some changes in the education world and learning environments. In this context, it is wondered how the students' attitudes, motivations, and satisfaction with e-courses are based on universities' applications, which took a break from face to face education and continuing their practices with e-learning platforms. Besides, the effects of students' socioeconomic status on e-learning and teachers' adaptation to innovativeness are among the other topics.

Objective: This study aims to reveal the perception of university students' satisfaction for the ecourses they have received during the Covid-19 pandemic and the level of teacher innovativeness that predicts student satisfaction for e-learning. Answers to the following questions have been sought to achieve this goal.

\section{Research Questions}

i. What are the participants' satisfaction levels with e-learning practices and their opinions about teacher innovativeness in the pandemic process?

ii. Do the participants' satisfaction regarding e-learning practices and teacher innovativeness in the pandemic process show a significant difference according to gender, mother, and father education level?

iii. Is there a substantial difference between the participants' satisfaction for e-learning practices and their opinions about teacher innovativeness in the pandemic process, according to the family income status, the part that the participants are studying, and how many hours a week they use the internet for course purposes?

Turkish Studies, 15(6) 
iv. Is there a significant relationship between participants' perceptions of e-learning satisfaction in the pandemic process and teacher innovativeness, family income status, internet use for teaching purposes, and parents' education status?

v. Are participants' perceptions of e-learning satisfaction in the pandemic process a significant predictor of teacher innovativeness?

Method of the Study: The study sample consists of 263 university students studying through ecourses in science and education faculties of a private university in the Turkish Republic of Northern Cyprus (TRNC) and selected by a simple random sampling method from different grade levels. The 'satisfaction scale for e-course' and the teacher innovativeness dimension used in TALIS 2018 were used as data collection tools.

Findings of the Research: When the students' opinions about e-courses satisfaction and teacher innovativeness are examined, general e-learning satisfaction of the students for the e-courses were found to be medium $(\overline{\mathrm{X}}=3.28)$. According to the results of the T-test, interest, satisfaction, and participants' motivation for e-course shows a significant difference for male participants by gender. On the other hand, there has been a considerable difference between female participants and gender in terms of taking the course face to face. Students' perception of teacher innovativeness does not differ significantly according to gender in e-courses has been determined. Interest, satisfaction, and motivation attitudes of participants whose mothers received high school or higher education have been found to show a significant difference in elesson practices. There has been no significant difference in any category according to the father's education level of the participants. According to the findings of the Anova test, there is a considerable difference between the groups regarding the participants' income status as only 'distance education motivates them.' According to the department where the participants' study, the interest, satisfaction, and motivation towards the e-course show a significant difference on behalf of the students of the information technology teaching department. No significant difference could be detected between teacher innovativeness and the education department. A significant difference between the interest of the participants for e-course and their general satisfaction with e-courses and the amount of weekly internet usage for educational purposes has been found on behalf of using computers for 'nine hours' or more. According to Pearson correlation analysis, there is a high level of positive $(r=.699, \mathrm{p}<.01)$ relationship between e-learning satisfaction of university students and teacher innovativeness and low significant relationships between internet use $(r=.283, p<.01)$ and mother education status $(\mathrm{r}=.155, \mathrm{p}<.05)$. According to the regression analysis of whether the participants' perceptions of teacher innovativeness are a significant predictor of e-learning satisfaction, teacher innovativeness $(\mathrm{R}=.699, \mathrm{p}<.05)$ was found to be a significant predictor of e-learning satisfaction $(\beta=.51, \mathrm{p}$ $<.05)$.

Results and Suggestions: It has been concluded that distance education courses offered to students during the pandemic are welcomed at a moderate level by students in all sub-dimensions. Interest, satisfaction, and motivation of male students for computer-assisted distance learning course activities differ significantly compared to female participants. However, female participants have been observed to diverge significantly in choosing to face to face learning. The interest, satisfaction, and motivation of participants whose mothers who received high school education or higher education were also higher than those of the participants whose mothers' education level is a secondary school and below. The participants' motivations from the low-income families of the e-course practices have been lower than those of coming from relatively higher-income families. According to the research results, preference for e-learning or face-to-face education shows a significant difference between students of the computer teachers department and the groups of other students who use the internet for lesson hours according to the level of education. There has been a high level of meaningful relationships between university students' e-learning satisfaction and teacher innovativeness, and it has been concluded that teacher innovativeness is a significant predictor of e-learning satisfaction. Developing teacher qualities are essential to increase student satisfaction in e-learning processes. In this context, it is recommended to prepare e-course materials, contents, learning environments, and learning communities as well as strengthening student-teacher interaction. At this point, highlighting the education policies towards improving the innovativeness levels of teachers might be significant. In-service practices, supportive and developer activities should be increased to solve the problem of teachers' and students' adaptation for distance learning in educational organizations, to develop content, and to free students from a passive and passive learning process of e-lesson environments. 
Keywords: Educational Sciences, teacher innovativeness, distance education, coronavirus, e-course satisfaction

Öz: Covid-19 pandemisi birçok ülkede toplu yaşama ilişkin süregelen bireysel, toplumsal, kamusal ve kurumsal eylemleri ve alışkanlıkları derinden etkilemiştir. Bu etkilenmenin en yoğun yaşandığı kamu kurumlarının birisi de alışılagelmiş eğitim ortam ve yöntemlerini hızlı bir şekilde değiştirmek ve dönüştürmek zorunda kalan eğitim örgütleri olmuştur. Bu araştırmada üniversite öğrencilerinin Covid-19 pandemi sürecinde almış oldukları e-derslere yönelik memnuniyet algıları ile öğretmen yenilikçiliğinin eöğrenmeye yönelik öğrenci memnuniyetini yordama düzeyi ortaya konulmak amaçlanmıştır. Araştırmanın örneklemini Kuzey Kıbrıs Türk Cumhuriyeti'nde (KKTC) özel bir üniversitenin fen edebiyat ve eğitim fakültelerinde e-dersler yoluyla öğrenim gören farklı sınıf seviyelerinden basit seçkisiz örnekleme yöntemi ile seçilmiş 263 üniversite öğrencisi oluşturmaktadır. Veri toplama aracı olarak 'E-derslere yönelik memnuniyet ölçeği' ile TALIS 2018'de kullanılan öğretmen yenilikçiliği boyutu kullanılmıştır. Veriler SPSS 23 paket programı ile analiz edilmiştir. Araştırmada betimsel ve kestirimsel istatistikler kullanılmıştır. Araştırmada e-derslere yönelik öğrenci memnuniyeti orta düzeyde olduğu, en düşük memnuniyetin materyal boyutunda, en yüksek memnuniyet ise öğrenci-öğretmen etkileşimi ve öğretmen yenilikçiliği boyutlarında olduğu sonucuna ulaşılmıştır. Cinsiyete göre erkek katılımcılar lehine, anne eğitim durumuna göre anneleri lise ve üzeri eğitim alan öğrenciler lehine e-ders etkinliklerine yönelik ilgi, memnuniyet ve motivasyon düzeylerinin yüksek olduğu bulgusuna ulaşılmıştır. Kadın katılımcılar ve Türkçe gurubu öğretmenlik bölümü katılımcıları yüz yüze öğrenme etkinliklerini daha çok tercih etme eğiliminde olduğu sonucuna da ulaşılmıştır. Ayrıca, okuduğu bölüme göre bilgisayar bölümü öğrencilerinin lehine, ders amaçlı internet kullanımına göre interneti daha çok kullananlar lehine anlamlı farklılıklar bulunmuştur. Son olarak, e-ders memnuniyeti ile öğretmen yenilikçiliği arasında güçlü bir korelasyon bulunmuş olup, öğretmen yenilikçiliğinin öğrencilerin e-ders memnuniyetinin anlamlı bir yordayıcısı olduğu sonucuna ulaşılmıştır. Eöğrenme süreçlerinde öğrenci memnuniyetinin artırılması için başta öğretmen niteliklerinin geliştirilmesi olmak üzere, öğrenci memnuniyetini öne çıkaran e-ders uygulamalarının tüm süreçlerinin titizlikle planlanması, hazırlanması ve uygulanması önerilmektedir.

Anahtar Kelimeler: Eğitim Bilimleri, öğretmen yenilikçiliği, uzaktan eğitim, coronavirüs, e-ders memnuniyeti

\section{Giriș}

Çin'de ilk olarak ortaya çıkan ve tüm dünyaya hızlı bir şekilde yayılarak pandemi haline dönüşen Covid-19 virüsü, birçok ülkede toplu yaşama ilişkin günlük ve iş hayatının alışkanlıklarını ve eylemlerini etkilemiş ve ulaşımdan alışverişe, özel işletmelerden kamu kurumlarının iş ve işleyiş̧ süreçlerini büyük ölçüde değiştirmiştir. $\mathrm{Bu}$ etkilenmenin en yoğun yaşandığı ve değişimin/dönüşümün en çok hissedildiği alanlardan birisi de eğitim örgütleri olmuştur.

Covid-19 pandemi gerçeğiyle tanışan Türk milli eğitim sisteminin her kademesinde öncelikli olarak tedbir amaçlı eğitim öğretim süreçlerine ara verilmiştir. Pandemi sürecinin tüm dünyada olduğu gibi uzun sürme beklentisinin güçlenmesi ile birlikte okullarda yüz yüze eğitimin yerine ilkokul, ortaokul, lise ve yükseköğretim kurumlarında çevrim-içi e-ders eğitim süreçleri hızlı bir şekilde uygulamaya alınmıştır. Bu konuda daha önceki yıllardan Fırsatları Artırma ve Teknolojiyi Geliştirme Hareketi (FATİH) projesi ile teknolojiyi eğitim ortamlarıyla buluşturma amacıyla kurulan Eğitim Bilişim Ağı (EBA) yüz yüze eğitim yapılamamasından kaynaklanan eğitim açığını gidermede oldukça önemli bir rol üstlenmiştir. Bununla birlikte, yükseköğretim kurumlarındaki öğrenciler için de oluşan eğitim ve ders açığının giderilmesine yönelik de bir dizi tedbirler alınmıştır. Türkiye'de ve Kuzey Kıbrıs Türk Cumhuriyeti’ndeki (KKTC) üniversitelerde de yüz yüze öğretimden e-ders sürecine hızlı bir geçiş yapılmıştır. Ancak bu geçiş süreci her üniversitede aynı hızda, aynı zamanda ve aynı başarıda gerçekleşmemiştir.

E-öğrenme her ne kadar son on yıllardır eğitim örgütlerinde kısmen uygulanıyor olsa da, Türkiye'deki ve KKTC'deki üniversitelerde daha dar bir kapsamda uygulama alanı bulmuştur. 
Bununla birlikte, uzaktan eğitim çalışmalarının Covid-19 pandemisi öncesinde de birçok üniversitede uygulanmakta olduğu bilinmektedir. Bazı öğretim üyeleri özellikle geniş katılımlı derslerinde kendi e-içerik kayıtlarından faydalanırken, bazıları ise ters-yüz edilmiş sınıf yöntemlerini kullanmışlardır. Öğretim üyeleri bu etkinlikler sırasında ders içeriğinin teorik alt yapısını video kayıtlarından sunarken, yüz yüze ders sürecinde ise açık uçlu sorularla ve alıştırmalarla destekleyici e-öğrenme sistemlerini de kullanmışlardır. Ancak, üniversitelerin tüm bölümlerini öğretim görevlilerini ve öğrencilerini zorunlu olarak kapsayan bir uygulama söz konusu değildi. Pandemi süreciyle birlikte gündeme gelen ve yüz yüze eğitimin boşluğunu doldurmak üzere ikame edilmeye çalış1lan e- ders uygulamaları, teknolojinin bir eğitim aracı olarak daha radikal ve bir zorunluluk sonucu sisteme girmesini beraberinde getirmiştir.

E-öğrenme, 'Eğitim 4.0' yenilikçi uygulama araçlarından birisidir (Halili, 2019). Eğitim örgütleri için teknoloji temelli öğrenme-öğretme etkinliklerinin işe koşulması bağlamında faydalı olabilir. Ancak, öğrencilerin ve öğretim elemanlarının pandemi etkisiyle yüz yüze eğitimden uzaktan eğitime bu denli hızlı bir şekilde geçişleri beraberinde bazı sorunları getirmiştir. Mevcut bilişim teknolojileri internet yapısının yeterliliği, teknoloji destekli çevrimiçi (online) öğrenme materyallerinin çeşitliliği, öğretmenlerin e-dersler konusunda dijital yeterliliği, öğrencilerin tamamen çevrimiçi bir eğitim ortamında derslerini işlemeye uyum sağlamaları, motivasyonları, yüz yüze sosyal iletişim eksiklikleri alan yazında tartışılan başlıca sorunlar arasındadır (Carolan ve diğerleri, 2020).

Eğitim 4.0 uygulamalarını öne çıkaran birçok yenilikçi eğitim sistemlerinde e-öğrenme neredeyse yüz yüze eğitimi destekleyen güçlü bir akım haline gelmiş ve en geniş çapta da yükseköğretime uyarlanmıştır. Dahlstrom ve diğerleri (2014)'nin belirttiği gibi yükseköğretim kurumlarının büyük bir çoğunluğunun öğrenme yönetim sistemine (Learning Management System LMS) sahip olması bunu destekler niteliktedir. Alan yazında uzaktan eğitimin birçok avantajları ve dezavantajları bulunduğuna ilişkin tartışmalara rastlanmıştır. Bunlardan üniversite öğrencilerinin çevrim-içi ve dışı eğitim süreçlerine yüksek oranda katılımının nasıl sağlanacağı, uzaktan eğitim süreçlerine adaptasyonu, üniversitelerin uzaktan eğitim uygulamalarına hazır olup olmadığı ve eöğrenme süreçlerine direnç konularında literatürde birçok tartışmaların ve model önerilerinin (Ebner ve diğerleri, 2020) bulunması e-öğrenme alanına ilişkin eğitsel kaygılardan bazılarıdır. Bunula birlikte, Covid-19 pandemi sürecinde dünya genelinde üniversitelerin farklı uygulamaları olmakla birlikte e-ders uygulamalarına uzak coğrafi bölgelerden, evlerden katılım sağlanabilmesi en önemli avantajlarından birisi olarak görülmektedir. Ayrıca, istenilen zamanda ders kayıtlarının tekrar izlenilebilmesi ve öğrencilerin ders haricinde diğer işlerine daha fazla zaman ayırabilmesi, okula fiziki ulaşımdan vakit ve enerji tasarrufu sağlanması ve çevrimiçi sınav uygulamaları gibi esneklikler e-öğrenme uygulamalarının olumlu yüzü olarak ortaya çıkmaktadır (Teo ve diğerleri, 2020). Bu bağlamda pandemi sürecinde etkin olarak uygulanan e-öğrenme süreçlerinin öğrenciler nezdinde nasıl algılandığı ve yorumlandığı merak edilmektedir. Diğer taraftan, öğrencilerin mevcut e- ders uygulamalarından ve etkileşimlerden memnun olma düzeyleri ile uzaktan eğitime yönelik tutumları da merak edilen bir diğer konudur. Araştırma, e-öğrenmenin gelişimi, teknoloji ile eğitimin uyumlaştırılması ve yeni eğitim teknoloji ve içeriklerinin eğitim ortamlarında daha çok kullanılması bakımından önemsenmektedir. Covid-19 pandemisi gibi olağan dışı durumlarda eğitimin sürdürülebilirliği açısından da yeni bir perspektif sunar (Bozkurt, 2020). Pandemi süreci ile tartışmaların odağ 1 olan e-öğrenme uygulamalarının öğrenci perspektifinden algılanan kalitesi ve verimliliği de e-öğrenme uygulama ve süreçlerinin geliştirilmesine olumlu katkılar sunabilir.

\section{E-öğrenme, öğretmen yenilikçiliği ve BİT ilişkisi}

Öğrencilere öğrenmeyi desteklemek için web tabanlı ortamda esnek ve bireysel çalışma ortamı sunan (Clark \& Mayer, 2016; Kolburan Geçer \& Deveci Topal, 2015) uzaktan eğitim, canlı sohbet oturumları, e-posta, çevrimiçi tartışmalar, kısa sınavlar, forumlar ve ödevler aracılığıyla iletilen ses, video, metin yazıları gibi çok çeşitli öğretim materyallerini bütüncül bir şekilde entegre 
edebilen bir bilgi sistemidir (Lee ve diğerleri, 2011). Benzer şekilde, Haghshenas (2019) eöğrenmenin öğrenci kayıtları, sınavlar, ödevler, ders içerikleri, ders planları, mesajlar, eğitim programı, temel ders materyalleri gibi elemanların bir sistem içerisinde organize edilmesi ve yönetilmesini içeren bir sistem olduğunu belirtmiştir. Sun ve diğerleri (2008) ise e-öğrenmeyi öğrenme sürecine yapılan teknolojik müdahale olarak görmektedir. $\mathrm{Bu}$ teknolojik müdahale senkron veya asenkron olarak derslerin harici depolama araçlarıyla veya bulut depolama alanlarını kullanarak internet ortamında tutulması ve ilgili kişiye ulaştırılması, uygun içerik, resim, ses, görüntü veya yazı gibi medya enstrümanlarının öğretimsel süreçlere katılması olarak yorumlanmaktadır (Clark \& Mayer, 2016).

E-dersler uygulandıkları öğretim düzeyine ve derslerin çeşitliliğine göre değişen etkileşimli ortam tasarımları ve sunum teknikleri gerektirmektedir. Bununla birlikte kullanılan iletişim araçları ve materyaller, öğrenci-öğretmen etkileşimi, öğrenme süreci, ders içeriği ve değerlendirme gibi temel bir takım teknik ve etkileşimsel özellikler öğrenme-öğretme sürecini ve öğrenci ders memnuniyetini etkilemektedir (Genç \& Gümrükçüoğlu, 2020).

E-öğrenme sayesinde dünyanın her yerinde eğitimin her kademesine yönelik materyal hazırlama, kullanma ve paylaşma yaygınlaşmıştır. Böylece öğrencilere daha esnek bir çevrede eğitim sunulması sağlanmıştır. Günümüzde eğitime kolay ulaşılabilirlik fonksiyonu internet tabanlı öğrenme ortamları senkron veya asenkron dersler vasıtasıyla uzaktan öğrenme vasıtasıyla sağlanmaktadır. E-öğrenme teknolojileri ile öğrenci, içerik ve materyaller arasındaki etkileşim uzaktan öğrenmeyi eğitim süreçlerinin zorunlu bir parçası haline getirmiştir (Harandi, 2015). Bireyin kendi hızına ve stiline göre öğrenmesini sağlayan e-öğrenme uygulamaları günümüzde bir taraftan hızla üretilen bilgiye erişimi hızlandırıp öğrenilmesini kolaylaştırırken bir tarafatan da bireyin hayat boyu öğrenme süreçlerinde etkili bir eğitim ortamı olarak görülmektedir (Karahan ve diğerleri, 2020). Bu öğrenme ortamları video, ses, yazı, resim, online sinavlar, sanal sinıflar, wikiler, karşılıklı akran aktiviteleri, tartışma forumları gibi araçlar vasıtasıyla sürdürülebilmektedir (Kolburan Geçer \& Deveci Topal, 2015). Bireyin kendi kendine öğrenmesini teşvik eden ve coğrafi sınırları aşan farklı formatlardaki bu öğrenme kaynaklarına internet üzerinden erişilerek dünyanın hemen her yeriyle işbirlikli ve etkileşimli iletişim sağlanabilmektedir (Al-Fraihat ve diğerleri, 2020). Öğrenme-öğretme ortamlarında işbirlikçi yaklaşım ve etkileşimli iletişim 21. yüzyıl becerileri bağlamında da ele alınmakta ve küreselleșen dünyada Eğitim 4.0 yaklaşımının teknolojinin öğrenmeye entegrasyonu bağlamında anahtar kavramlarını oluşturmaktadır.

Gerek yüz yüze ve gerekse sanal ortamda olsun eğitim örgütlerinde eğitim uygulamalarının temel amacı öğrencileri eğitim programlarında hedeflenen bilgiler, beceriler ve tutumlar ile donatmaktır. Bu sebeple eğitim süreçlerinin öğrencilerin motivasyonlarını artırıcı, yaşlarına, psikolojik durumlarına ve bireysel özelliklerine uygun bir şekilde tasarlanması gerekmektedir (Demirel, 2015). Bu bağlamda tasarlanan eğitimin her kademesindeki uzaktan eğitim ortamlarının bir takım özellikler taşıması gerekir. Bu niteliklerden alanyazında e-öğrenme ortamlarında öğretmen-öğrenci etkileşimine ve öğretmenlerin geri dönüt sağlama sıklı̆̆ına (Young, 2006; Bangert 2004) vurgu yapan kanıtlara rastlanmıştır. Ayrıca, literatürde yenilikçi öğretmenlerin oluşturduğu etkileşimli ders ortamlarına ve olumlu öğrenme ikliminin önemine vurgu yapılmaktadır. Kaliteli ve yenilikçi bir uzaktan eğitim sağlanması e-ölçme ve değerlendirme araçlarının geliştirilmesine, ders programlarının sanal ortamdaki yenilikçi öğrenme-öğretme teknikleriyle bütünleştirilmesine, uygun ders görsellerine ve tartışma platformlarına yer verilmesine bağlıdır (Chaney, 2007).

Kalite odaklı eğitim reformları giderek teknoloji ile eğitim içerik, süreç, uygulama ve eğitim ortamlarının bütünleşmesine doğru ilerlemektedir. Bu bağlamda yenilikçi bir uygulama olan uzaktan öğrenmenin başarısı, yenilikçi öğretmen işbirliğine, güçlü bir program yapısına, paydaşların ihtiyaçlarına, iletişim teknolojileri alt yapısına, hedef kitleye uyumlu öğrenme materyallerine, öğrenme-öğretme yöntem ve teknikleri ile eğitim yaşantılarına bağlıdır. Daha da 
önemlisi bu gelişmelere liderlik edecek okul yönetimine ve eğitimde politika yapıcılarla karar vericilerin uyumlu ve senkronize çalışmalarıyla ilişkilidir.

Bazı eğitim sistemleri, teknolojiyi öğrenme ve öğretme süreçlerine taşıma konusunda oldukça önemli atılımlar gerçekleştirmekte ve e-öğrenme gibi teknoloji tabanlı eğitim uygulamalarını politika gündemlerine almaktadırlar. Covid-19 pandemi sürecinde, BİT (Bilgi ve İletişim Teknolojileri)'e dayalı uzaktan eğitim kapsamında birçok ülke yenilikçi e-öğrenme plarformlarını geliştirmiștir. Bu ülkelerden birisi de Endonezya'dır. Hükümet yetkilileri ve eğitim bakanlığ Covid-19 salgınıyla başa çıkabilmek amacıyla okullar ve yükseköğrenim enstitülerinde kullanılmak üzere tasarlanan "Rumah Belejar" ücretsiz çevrim-içi öğrenme platformunu ve Araştırma Teknoloji ve Yüksek Öğretim Bakanlığı tarafından kurulan "SPADA" adı verilen üniversite öğrencileri için e-öğrenme platformu oluşturmuşlardır (Mailizar ve diğerleri, 2020).

Yenilikçi uzaktan öğrenme programlarından bir tanesi de Çin'de eğitim bakanlığ tarafından uygunlalan (2011-2020) eğitimde on yıllık kalkınma planıdır. Bu kapsamda bir eğitimsel bulut kaynak platformu inşa edilerek yüzlerce şirket ve binlerce öğretmen-öğrenci ortak bir platformda buluşturulmak suretiyle birçok eğitim kaynağı meydana getirilmiştir. Ayrıca, Çin'de yenilikçi e-öğrenme uygulamalarına yönelik olarak eğitimin yönetimine ve gelecekteki gelişmelere göre uyarlanabilir platformlar vasıtasıyla bireylerin okul internet ağları üzerinden sınıf seviyelerine uygun eğitim kaynaklarına erişimi sağlanmaktadır (Dai \& Xia, 2020). BİT kullanılarak yenilikçi bir yaklaşımla tasarlanan bir diğer e-öğrenme platformu ise Çin eğitim bakanlığı tarafından 2016 y1lında uygulamaya konulan "Day Day Up" platformudur. Bu platform, inovatif bir yakalaşımla vücuda getirilen sınıf öğrenme ortamı sunmak için ağ tabanlı yaygın öğrenmeye, eğitimde bilgiden öte uygulama düzeyini geliştirmeye ve bilgi teknolojisi ve eğitimin bütünleşik gelişimini derinleştirmeye yönelik hazırlanan ağ tabanlı kapsamlı öğrenmeyi desteklemeye odaklanmaktadır. Dünyada kitlesel açık erişim dersler eğitim ortamlarını kampüslerin dışına çıkararak daha geniş kitlelerin eğitime kolayca erişebilmesini sağlamıştır (Sezgin, 2020). Bu kapsamda geliştirilen bir uygulama da Çin eğitim bakanlığının üç ana değişimi hedefleyen politika girişimidir. Bu politika girişimlerinden birincisi küçük ölçekli özel kaynaklardan bulut depolama gibi büyük ölçekli kaynakların kullanımına geçilmesidir. İkincisi öğrencilerin uygulama yeteneklerini geliştirmekten bilgi teknolojilerine kadar teknoloji okuryazarlıklarının geliştirilmesidir. Üçüncü politika girişimi ise uygulama entegrasyonu geliştirmekten yenilikçi entegrasyonu geliştirmeye kadar geniş bir yelpazeyi içermektedir (The Ministry of Education of China, 2016). Benzer bir politika uygulaması, Milli Eğitim Bakanlığı Yenilikçilik ve Eğitim Teknolojileri Genel Müdürlüğü bünyesinde kurulan EBA uygulamalarıdır. EBA 23 Mart-30 Nisan 2020 tarihleri arasında pandemi sürecinde etkin bir rol oynamış, 1.2 milyarı aşan tıklanma ile, 6 milyon 90 bin 383 aktif öğrencisi ile, 978 bin 313 canlı ders etkinlikleri ile kendi rekorunu kırarak dünyada altıncı sırada yer almakta (MEB, 2020) ve Çin'den sonra örnek ikinci platform olarak gösterilmektedir.

Türkiye'de Eğitim ve Bilişim Ağı (EBA) çevrim-içi platformu ilkokul, ortaokul ve lise düzeyinde uzaktan eğitim hizmetlerinde hızlı bir şekilde kullanıma sunulmuştur. Sistem üzerinde öğretmenlerin ders konuları ile ilgili video çekimleri, soru paylaşımları ve ulaşılabilir ders kaynakları önemli bir yer tutmaktadır. Pandeminin ilerleyen dönemlerinde öğretmenler dizüstü, masaüstü bilgisayarlar ve webcam aracıllğıyla her ders için kendi okul öğrencilerine ayrılan vakitlerde canlı ders yaparak EBA sistemini aktif bir şekilde kullanmışlardır. Yükseköğrenimde ise e-öğrenme her üniversitede de uygulanmakla birlikte üniversitelerin alt yapısına göre farklılık göstermiştir. Çevrim-içi canlı dersler, video çekimli derslerin yanı sıra çevrim-içi sınav sistemleri de aktif bir şekilde kullanılmıştır. Çevrim-içi öğrenmelerin geleneksel öğretim modelleri kadar başarılı ve etkili olduğuna dair kanıtlar mevcuttur (Pei \& Wu 2019; McCutcheon ve diğerleri, 2015). Bunun için öğretmenlerin yenilikçi bir tutum sergilemesi ve öğrencilerin öğrenme motivasyonlarının yüksek olması önemli iki ana noktadır. Bertiz (2017)'in EBA'nın etkililiğine yönelik yaptığı bir araştırmada öğrencilerin EBA platformunu kolaylıkla kullanabildikleri, platformu kullanım esnasında teknik desteğe ihtiyaç duymadıkları, sistemin hızlı ve kullanımının 
kolay olduğu ortaya konulmuştur. Türkiye'deki ve KKTC'deki üniversitelerde yürütülen eöğrenme platformlarında ise daha ziyade 'Zoom' ve 'Teamlink' gibi çevrimiçi paylaşım uygulamalarının kullanıldığı bilinmektedir. Bu paylaşım siteleri aracılığı ile sunulan e-öğrenme hizmetinin öğrenci memnuniyetine ilişkin sınırlı sayıda araştırma bulunmaktadır. Bunlardan, Roskvist ve diğerleri (2020)'nin yaptığı bir çalışmada, tıp öğrencilerinin Zoom gibi haberleşme programları üzerinden karşılıklı olarak pratik yapmaları sağlanmıştır. Araştırmada, videolar, canlı yayınlar, web konuşmaları ile sürdürülen çevrim-içi öğrenmelerin teorik bilgileri edinmede etkili olduğu belirtilmiş, öğrencilerin başarılarının hazırlanan çevrim-içi portfolyolar ile değerlendirildiği ifade edilmiştir. Uygulamalı eğitimlerde çevrim içi öğrenmeler öğrencileri bir kısım hedeflere ulaştırmakla birlikte, bu durumun mesleki eğitim açısından ne kadar sürdürülebilir olduğu net değildir. Bu bağlamda eğitimin tamamen çevrim-içi olması yerine karma eğitimin benimsenmesi de yükseköğrenimde uzaktan eğitim için işaret edilen modellerden bir tanesidir.

Öğretmen yenilikçiliği öğretme ve öğrenme için yeni fikirler geliştirmeye, değişime açıklıkla, problem çözmek için yeni yollar aramak ve yeni fikirlerin uygulanması için birbirlerine pratik destek sağlamakla ilişkilidir (Akar, 2019). Öğretmen yenilikçiliği, e-öğrenme süreçlerinin başarısında ve öğrencilerin tatmininde öğretmenin önemli bir rol oynadığı ilgili literatürdeki araştırmalarda kanıtlanmıştır (Cidral ve diğerleri, 2018; Lwoga, 2014; Mtebe \& Raphael, 2018; Sun ve diğerleri, 2008). İlgili araştırmalarda e-öğrenme süreçlerinde öğretmen niteliğinin önemli bir yer tuttuğu (Cheng, 2012; Kim ve diğerleri, 2012), e-öğrenme uygulamalarında öğrenci memnuniyetinin öğretmen kalitesiyle pozitif bir ilişki sergilediği (Al-Fraihat ve diğerleri, 2020) ortaya konulmuştur. Buna karşın, büyük bir grup üniversite öğretim üyesinin çevrim-içi eğitim dersleri yapamayacaklarını belirten bir araştırmaya da rastlanmıştır (Ebner ve diğerleri, 2020). Eöğrenmeye karşı uyum sağlayamama ve direnç gösterme ihtimali de eğitim kurumlarında karş1laş1labilecek olası bir durumdur. Nitekim yükseköğretimde e-öğrenmeye karşı direnç ve dezavantajları ele alan çalışmalar da (Islam ve diğerleri, 2015) alanyazında mevcuttur. King ve Boyatt (2015) ise bazı üniversitelerin veya üniversite bölümlerinin e-öğrenme konusunda neden ve nasıl diğer üniversite veya bölümlere göre daha yüksek e-öğrenme uygulama oranlarına sahip olmalarında farklı yaklaşımların, teorilerin ve modellerin etkili olduğunu belirtmektedir. Farklılaşmanın temelde kurumsal altyapıdan, öğretmen tutum ve becerilerinden, algılanan öğrenci beklentilerinden kaynaklandığına vurgu yapılmaktadır. Bu araştırmada öğretmen yenilikçiliğinin öğrencilerin e-öğrenmeye ilişkin memnuniyet algılarını yordama düzeyi araştırılmak istenmiştir.

\section{E-öğrenme ve öğrenci tutumu}

Öğrenmenin gerçekleşmesi bireyde olumlu tutumların geliştirilmesine ve öğrenmeye karş1 içsel motivasyonunun harekete geçirilmesi ile yakından ilişkilidir. Motivasyon öğrenmenin itici gücü olarak tanımlanabilir (Paris \&Turner, 1994). Brophy (2010) motivasyonu davranışların neden başladığını, davranışların yönelimlerini, davranışın meydana gelme yoğunluğunu, kalıcılığını, niteliğini ve bilhassa hedefe yönelik davranışı açıklayan teorik bir yapı olarak tanımlamaktadır. Ryan ve Deci (2000) motive olmuş bireylerin zorlayıcı aktiviteleri gögü̈sleyen, aktif katılım gösteren, öğrenmekten zevk alan ve derinlemesine adapte olan, yüksek performans gösteren, 1srarc1 ve yaratıcı özellikler gösterdiğini belirtmişlerdir. Motivasyon aslında göründüğünden daha karmaşık bir konu olmakla birlikte içsel motivasyonun doğuştan gelen bir kalıcı kişilik özelliği olduğu (Deci \& Ryan, 1985) ifade edilmektedir. İçsel motivasyon, çevrimiçi öğrenmelerde eöğrenenlerin önemli bir özelliğidir (Shroff \& Vogel, 2009). Dışsal motivasyon ise kazanımlara bağlı olarak kişiden kişiye değişen bir özellik (Bandura, 2002) olarak yorumlanmaktadır. Bu tanımlardan hareketle, bireyde içsel ve dişsal motivasyonun yüksek olması eğitim ortamları için arzu edilen bir durum olduğu söylenebilir.

Yüz yüze ders ortamlarında öğrenci motivasyonunu artırmak için birçok etkinlik uygulanabilmektedir. Fakat çevrim-içi eğitimde durum biraz daha zor, karmaşık ve farklıdır. Öğrencinin duygu ve düşüncelerini aktarabildiği fiziksel bir ortamın yerine sanal bir ortamda, 
kendisini sinıf ortamından kopuk hissetmesi (Paulus \& Scherff, 2008), adaptasyon sorunu yaşaması, teknolojiyi verimli kullanamamanın verdiği üzüntü (Hara \& Kling, 2003) ve diğer sinırlılıklar öğrenci motivasyonu üzerinde olumsuz bir etki yapabilmekte ve e-öğrenme sürecini terketmesine sebep olabilmektedir. Buna karşın, öğrecileri program hedeflerine taşıması için, Web tabanlı internet ortamlarında e-öğrenme sistemlerinin öğrencileri içselleştirebileceği bir ortam tasarımının da motivasyon sağlanması bakımından önem arz ettiği düşünülmektedir. Keller ve Suzuki (2004) öğrenci motivasyonu ve e-öğrenme tasarımı üzerine yaptıkları çalışmada, e-öğrenme ortamlarında motive edici öğrenme çevresinin motivasyonel yönüne odaklanan eğitim tasarımı modeli ARCS (Dikkat, uygunluk, güven, doyum) modelinin öğrencilerin e-öğrenmeyi bırakmada azalma sağladığını ve diğer olumlu motivasyonel sonuçlara ulaştığını belirtmiş̧lerdir. Keller (2008) öğrenci motivasyonunu sağlanmasının çevrim-içi eğitimin verimliliği ve başarısı için temel gereksinimlerden biri olduğunu belirtmiştir. E-öğrenme sistemlerinin başarıya ulaşması için eöğrenme platformlarının kullanışlılığının yanısıra (Almaiah, 2018) öğrencinin e-öğrenmeyi kabullenmesi, başarılı e-öğrenme sisteminin temel gereksinimlerinden birisi olarak kabul edilmektedir (Almaiah ve diğerleri, 2020). Memnuniyet hem bilgi sistemlerinin hem de e-öğrenme sistemlerinin başarısının kanıtlanmasında geçerliliği ve güvenirliliği ispatlanmış önemli bir göstergedir (Al-Fraihat ve diğerleri, 2020). Hassanzadeh ve diğerleri (2012) ise e-öğrenme sistemi kullanıcılarının bu platformlardan memnun kaldıklarında e-öğrenme sistemlerini daha fazla kullanarak azami fayda sağlayacaklarını belirtmektedirler. Bu durum teknoloji kabul modelleri ile açıklanabilir. Nitekim Torun ve Cengiz (2019) tarafından teknoloji kabul düzeyine (TKM) yönelik yapılan bir araştırmada TKM'si yüksek ve olumlu olan öğrencilerin dijital uygulamalara yönelik pozitif alg1 geliştirdikleri tespit edilmiştir. E-öğrenme platformaları öğrencilerin öğrenme düzeylerini ve performanslarını artırmasına, daha az emek harcayarak hedeflerine ulaşmayı kolaylaştırmasına ve böylece daha etkili ve kalıcı öğrenmeler gerçekleştirmesine paralel olarak öğrencilerin memnuniyet düzeylerinin de artmasına, e-öğrenmeye karşı olumlu tutum geliştirmelerine ve yüksek motivasyona erişmelerine katkı sağlamaktadır (Cidral ve diğerleri, 2018; Ghazal ve diğerleri 2018; Lwoga, 2014).

Öğrenci ihtiyaçları doğrultusunda hizmete sunulmuş etkileşimli bir e-öğrenme sistemi öğrencilerin ders başarısına ve çevrim-içi eğitim platformlarına yönelik olumlu bir tutum sergilemelerini destekleyecektir. Ayrıca, e-öğrenme sistemleri ile öğrenciler daha az zaman ve malzeme harcayarak optimum düzeyde fayda sağlayabilecektir (Al-Fraihat ve diğerleri, 2020; Cidral ve diğerleri, 2018). Bunu sağlamanın yolu, ders içerik ve ortamlarının öğrencilerin ilgisini çekebilecek şekilde tasarlanmasından, e-öğrenme materyallerinin zenginleştirilmesinden, animasyon, video gibi ders araçlarının etkili ve yerinde kullanılmasından, e-öğrenme değerlendirme araçlarının geliştirilmesinden ve öğrenmeyi sertifikasyonlandırmadan geçmektedir (El-Seoud ve diğerleri, 2016).

\section{E-öğrenme, yenilikçilik ve sosyoekonomik bağlam}

Gelişen iletişim teknolojileri bir taraftan e-öğrenme kullanımını kolaylaştırırken, diğer taraftan da kullanıcıların yüklenmesi gereken yeni bir ek iletişim ve teknoloji maliyetini de beraberinde getirmektedir. E-öğrenmenin en büyük özelliği internet tabanlı olması ve heryerden ulaşılabilirliğidir. Ayrıca internet tabanlı bu eğitim platformlarından faydalanmak için dizüstü bilgisayar, akıllı telefon, tablet gibi görece pahalı yeni teknoloji barındıran cihazların kullanılması gerekmektedir. E-öğrenme platformlarını kullanan öğrencilerin başarısını etkileyen birçok faktör vardır. Öğrencilerin çevrim-içi eğitim platformlarını kullanabilmek için gerekli bilgi ve beceriye sahip olmamaları çevrim-içi platformlarda başarı düzeylerini etkilediği gibi, internet bağlantıları ve e-öğrenmede kullanılacak cihazlarının olmaması ya da akranlarına göre daha ileri yaşlarda ulaşılması da başarı düzeylerini etkileyebilmektedir (Mailizar ve diğerleri, 2020). Wojciechowski ve Palmer (2005) de çevrim-içi öğrenme sistemleri ile öğrencilerin sosyo ekonomik düzeyleri arasında anlamlı ilişkiler olduğunu gösteren kanıtlar tespit etmişlerdir. Bu kanıtlar sosyo-ekonomik bağlamın öğrencilerin uzaktan eğitim araçlarına ulaşmadaki engellerini anlamada yardımcı olabilir. 
Uzaktan öğrenme engelleri ailenin sosyo-ekonomik statüsü ile doğrudan ilişkilidir. Berge (2013) araştırmasında uzaktan öğrenmeleri kısıtlayan engelleri bilişsel mesafe, bağlamsal mesafe, kültürel mesafe, duygusal mesafe, dil mesafesi, pedagojik mesafe, fiziksel mesafe, sosyal mesafe (sosyo eknomonik mesafe), teknik ve geçici mesafe olarak sıralamaktadır. Muilenburg ve Berge (2005) ise çevrimiçi öğrenmenin önündeki engelleri idari konular, sosyal etkileşim, akademik beceriler, teknik beceriler, öğrenen motivasyonu, çalışmalara zaman ve destek, internet maliyeti ve erişim ve teknik problemler olarak sekiz faktör altında sıralamışlardır. Buna karşın, Avrupa komisyonu (2013) raporunda dijital teknolojinin bazı faydalarının dezavatanlı gruplar için daha uygun olduğunu, bu grupların avantajlarının sadece uzak mesafelerden eğitim almak değil aynı zamanda eğitim harcamalarını da azaltmak yönünden faydalı olduğunu belirtmiştir. Diğer taraftan, Rose ve Blomeyer (2007) her öğrencinin kendine ait bir bilgisayarının olduğunu var saymanın ve her bireyin internet erişimine sahip olduğunun kabul edilmesinin gerçekçi bir durum olmadığının altını çizmektedir. Margarida ve Federico (2017) ise sosyo ekonomik bakımdan dezavantajlı grupların dijital teknolojilerden daha fazla yararlanabilmesine olanak sağlayacak materyaller sağlanması gerektiğine vurgu yapmaktadır ve bu dezavantajlı grupların dijital teknolojilere yönelik becerilerinin, onlara sağlanacak sosyal desteğin, motivasyonun ve tutumların çok boyutlu bir yaklaşımla ele alınması gerektiğini öne sürmektedir.

Alanyazında dijital teknolojilerin kendi kendilerine pozitif etkiler oluşturmayacağını, tam tersine entelektüel ve sosyal bir güçlendirici vazifesi görerek daha çok başarılı okullar ile az başarılı okullar arasındaki boşluğu daha çok büyüteceğini savunanlar da bulunmaktadır (Warschauer ve Matuchniak, 2010). Bu görüşe göre, uzaktan eğitim gibi uygulamalar öğrenmedeki devamlılıklarını sürdürmeye çalışan dezavantajlı öğrencilere sosyal destek sağlanamağı zaman zararlı olabilir. BİT'in uygun olmayan şekilde kullanımı, dezavantajlı öğrencileri öğretmenlerinden, diğer öğrencilerden ve başarılarını destekleyebilecek toplumdan izole etme tehlikesi de vardır (Margarida \& Federico, 2017). Bu bağlamda e-öğrenmenin sosyoekonomik durumun avantajları ve dezavantajları olabileceği gibi öğrenme sürecinin iyi yönetilmesi durumunda sosyoekonomik olarak dezavantajlı gruba olumlu katkılar sağlayacağı söylenebilir. Bu bağlamda, e-öğrenme çıktıları eğitim kurumlarının gelecek yönetim ve liderlik süreçlerine de yansımaları olabileceği düşünülmektedir.

Türkiye ve KKTC eğitim örgütlerinin her kademesinde yüz yüze eğitim yaygın olarak verilmekteyken, Covid-19 pandemisi ile birlikte e-öğrenme eğitim hayatımızın merkezine girmiştir. Covid-19 pandemisi toplumun yaşam alışkanlıklarında köklü değişiklikler meydana getirmekle kalmamış, eğitim dünyasında, öğrenme çevrelerinde de bir takım değişikilikler meydana getirmiş̧ir. $\mathrm{Bu}$ bağlamda araştırmamızda yüz yüze eğitime ara verip e-öğrenme platformları ile faaliyetlerini sürdüren üniversitelerin e-öğrenme platformlarındaki uygulamalarından öğrenci tutumları, motivasyonları, memnuniyetlerinin nasıl etkilendiği merak edilmektedir. Ayrıca, öğrencilerin sosyoekonomik durumlarının e-öğrenme ortamlarına etkisi ve öğretmenlerin yenilikçiliğe karşı uyumları da merak edilen diğer konular arasındadır.

Araştırma, Covid-19 pandemisinden dolayı eğitimsel uygulamaların hızlı bir şekilde yüz yüze eğitim ortamlarından dijital ortamlara ortamlara transferinden sonra e-öğrenme platformlarını kullanan ve e-öğrenme süreçlerinden doğrudan etkilenen kişiler olarak öğrencilerin görüşlerinin ortaya konulması, öğretmen yenilikçiliğinin ve çevrimiçi eğitim ortamlarnının kullanıcılar gözünde verimliliğinin değerlendirilmesi bakımından önem arz etmektedir. Bu çalışmada araştırmaya konu olan üniversite öğrencilerinin Covid-19 pandemi sürecinde almış oldukları e-derslere yönelik algıları ile öğretmen yenilikçiliğinin e-öğrenmeye yönelik öğrenci memnuniyetini yordama düzeyi ortaya konulmak amaçlanmıştır. Bu amaca ulaşmak için aşağıdaki sorulara yanıtlar aranmıştır.

\section{Araştırma Soruları}

i. Katılımcıların pandemi sürecinde e- öğrenme uygulamalarına yönelik memnuniyetleri ile öğretmen yenilikçiliğine ilişkin görüşleri nasıldır? 
ii. Katılımcıların pandemi sürecinde e-öğrenme uygulamalarına yönelik memnuniyetleri ile öğretmen yenilikçiliğine ilişkin görüşleri cinsiyet, anne ve baba eğitim düzeyine göre anlamlı bir fark göstermekte midir?

iii. Katılımcıların pandemi sürecinde e-öğrenme uygulamalarına yönelik memnuniyetleri ile öğretmen yenilikçiliğine ilişkin görüşlerinin aile gelir durumuna, katılımcıların okuduğu bölüme ve ders amaçlı haftada kaç saat internet kullandıkları değişkenlerine göre anlamlı bir fark var mıdır?

iv. Katılımcıların pandemi sürecinde e-öğrenme memnuniyeti algıları ile öğretmen yenilikçiliği ve ders amaçlı internet kullanımı değişkenleri arasında anlamlı bir ilişki var mıdır?

v. Pandemi sürecinde katılımcıların e-öğrenme memnuniyeti algıları öğretmen yenilikçiliğinin anlamlı bir yordayıcısı mıdır?

\section{Yöntem}

$\mathrm{Bu}$ araştırmada, Covid-19 pandemisi sürecinde üniversite öğrencilerinin uzaktan eğitim deneyimlerinin çeşitli değişkenler açısından incelenmesi araştırıldığından, veri toplama ve analiz süreçlerinde nicel araştırma tasarımlarından ilişkisel tarama modeli kullanılmıştır. İlişkisel tarama modeli mevcut örneklem üzerinde belli bir konuda tarama yapılarak uygulanır. Tarama araştırmaları önceden belirlenmiş bir konu, durum veya olaya ilişkin katılımcı görüşlerinin veri toplama araçlarıyla toplanıp analiz edilerek ortaya konulduğu araştırmalardır (Büyüköztürk ve diğerleri, 2016). Bu araştırmada da pandemi sürecinde yapılan e-ders uygulamalarının üniversite öğrencilerinin algılarına göre memnuniyetlerinin değerlendirilmesi amaciyla e-anket yoluyla konuya ilişkin veriler toplanıp analiz edilmiştir.

\section{Evren ve Örneklem}

$\mathrm{Bu}$ araştırmada evreni, 2019-2020 öğretim y1lı bahar döneminde KKTC'de özel bir üniversite'de e-dersler yoluyla uzaktan eğitim alan Fen Edebiyat Fakültesi ile Eğitim Fakültesi öğrencileri oluşturmaktadır. Covid-19 pandemisi sebebiyle ilgili üniversitede yüz yüze eğitime ara verilmiş ve bütün dersler zorunlu olarak e-ders platformları üzerinden yapılmaya başlanmıştır.

Araştırmayı sürdürmek için evrenin bütün üyelerinden veri toplamak imkânsız ya da çok maliyetli olabilir. Bunun için araștırmalarda örneklem kullanılır (Büyüköztürk ve diğerleri, 2016). Araștırmada basit seçkisiz örnekleme yöntemi kullanılmıştır. Bu amaçla, KKTC'de özel bir üniversitenin fen edebiyat ve eğitim fakültelerinde e-dersler yoluyla öğrenim gören ve gönüllülük esasına göre araştırmaya katılan farklı sınıf seviyelerinden rastgele seçilmiş 263 üniversite öğrencisi örneklemi oluşturmaktadır. Basit seçkisiz örnekleme, her bir örneklem elemanının seçimine eşit seçilme şansı verilerek seçilen elemanların örneklem kümesine alındığı yöntemdir (Büyüköztürk ve diğerleri, 2016). Bu araştırmada ulaşılan örneklem sayısı \%95 güven aralığına göre yeterli bulunmuştur. 
Tablo 1: Katılımcılara ilişkin demografik ve betimsel özellikler

\begin{tabular}{|c|c|c|c|}
\hline \multicolumn{2}{|c|}{ Değișkenler } & $f$ & $\%$ \\
\hline \multirow{3}{*}{ Cinsiyet } & Kadın & 145 & 55,1 \\
\hline & Erkek & 118 & 44,9 \\
\hline & 1. Sinıf & 19 & 7,2 \\
\hline \multirow{3}{*}{ Sınıf düzeyi } & 2. sinif & 40 & 15,2 \\
\hline & 3. sinif & 99 & 37,6 \\
\hline & 4. sinif & 105 & 39,9 \\
\hline \multirow{2}{*}{ Anne eğitim düzeyi } & Ortaokul ve altı & 132 & 50,2 \\
\hline & Lise ve üstü & 131 & 49,8 \\
\hline \multirow{2}{*}{ Baba eğitim düzeyi } & Ortaokul ve altı & 118 & 44,9 \\
\hline & Lise ve üstü & 145 & 55,1 \\
\hline \multirow{3}{*}{ Gelir durumu } & Üç bin liranın altında & 37 & 14,1 \\
\hline & Üç binden altı bin liraya kadar & 102 & 38,8 \\
\hline & Altı bin ve üzeri & 124 & 47,1 \\
\hline \multirow{4}{*}{ Okuduğu bölüm } & İngilizce öğretmenliği & 88 & 33,5 \\
\hline & Psikolojik Danış. Reh. & 51 & 19,4 \\
\hline & Bilişm teknolojileri öğretmenliği & 45 & 17,1 \\
\hline & Türkçe ve Sınıf öğretmenliği & 79 & 30,0 \\
\hline \multirow{4}{*}{ İnternet kullanımı } & Üç saatten daha az & 46 & 17,5 \\
\hline & Beş saate kadar & 85 & 32,3 \\
\hline & Dokuz saate kadar & 80 & 30,4 \\
\hline & Dokuz saat ve üstü & 52 & 19,8 \\
\hline
\end{tabular}

Tablo 1'de örnekleme seçilen katılımcıların demografik ve betimsel özellikleri verilmiştir. Buna göre, katılımcıların oransal olarak \%55,1 kadın ve \%44,9 oranında erkek katılımcıdır. Her sınıftan en fazla katılımcının dördüncü sınıflardan oluştuğu görülmektedir. Katılımcılarının annelerinin yaklaşık yarısının eğitim düzeyi $(50,2)$ ortaokul ve altı iken diğer yarısının $(\% 49,8)$ ise lise ve üstü olduğu görülmektedir.

Katılımcıların baba eğitim durumu ise ortokul ve altı \%44,9 iken lise ve üstü $\% 55,1$ 'dir. Gelir durumunda ise katılımcıların en çok $(\% 47,1)$ altı bin TL ve üzeri gelir grubunda olduğu tespit edilmiştir. Katılıncıların gelir düzeylerinin üç bin TL'nin altında olan \%14,1, üç bin ve beş bin arasında olan ise $\% 38,8$ olarak görülmektedir.

Katılımcıların öğrenim görüdüğü bölüm baklımında dağılımı ise İngilizce öğretmenliği \%33,5; Türkçe ve Sınıf öğretmenliği \%30; Psikolojik Danışmanlık ve Rehberlik \%19,4 ve Bilişim Teknolojileri öğretmenliği 17,1 oranındadır. Eğitim amaçlı internet kullanımı haftada en fazla beş saat olarak \%32,3'lük bir katılımcı kitlesi tarafından seçilmiştir. Dokuz saate kadar eğitim amaçlı interneti kullanan $\% 30,4$ iken dokuz saat ve üzeri \% 19,8 ve üç saatten az olan $\% 17,5$ oranındadır.

\section{Veri Toplama Araçları ve Verilerin Toplanması}

$\mathrm{Bu}$ araştırmada veri toplama aracı olarak Geçer Kolburan ve Deveci Topal (2015) tarafından geliştirilen 'E-derslere yönelik memnuniyet ölçeği' kullanılmıştır. Ayrıca TALIS 2018'de (Teaching and Learning International Survey) kullanılan ve açık erişime sunulan öğretmenlerin yenilikçiliğine dair dört madde de kullanılmıştır. Öğretmen yenilikçiliğine dair maddeler şunlardır: "Bu okuldaki öğretim üyeleri, öğretme ve öğrenme için yeni fikirler geliştirmeye çalışırlar", "bu okuldaki öğretim üyeleri değişime açıktır", "bu okulda öğretim üyeleri, problem çözmek için yeni yollar ararlar", "bu okulda öğretim üyeleri, yeni fikirlerin uygulanması için birbirlerine pratik destek sağlarlar." E-derslere yönelik memnuniyet ölçeği'nde açımlayıcı faktör analizine (AFA) göre 35 madde toplam beş faktör altında toplanmış olup varyansın \%67,61'ini açıklamaktadır. "E-derslere yönelik memenuniyet" ölçeği 5'li likert tipinde olup 
"Tamamen Kat1liyorum" (5), [4.20-5.00], Kat1liyorum" (4), [3.40-4.19], "Kismen kat1liyorum" (3), [2.60-3.39], "Kat1lmiyorum" (2), [1.80-2.59] ve "Kesinlikle Katılmıyorum" (1), [1.00-1.79] arasında sıralanan skala ve puan aralıklarından oluşmaktadır. Ölçeğin Cronbach alfa güvenirlik katsayısı 0.96 olarak hesaplanmıştır. Veriler 2019-2020 akademik yılı bahar döneminde toplanmıştır. Covid-19 pademisi sebebiyle uzaktan eğitim alan üniversite öğrencilerine "Google form" üzerinden elektronik anket yöntemi ile toplanmıştır. Araştırmanın yürütülmesi için gerekli idari izin, etik kurul onayı ile ölçeklerin kullanımına ilişkin araştırmacı izinleri alınmıştır. Elektronik anket formu üniversitenin fen edebiyat ve eğitim fakültesi öğrencilerinin tümüne gönüllülük esası gözetilerek e-posta adreslerine ulaştırılmıştır. Analizler 263 öğrencinin dönütlerine göre yapılmıştır. Araştırma için ilgili kurumdan etik kurul izni alınmıştır.

\section{Verilerin Analizi}

$\mathrm{Bu}$ araştırmada verilerin analizinde SPSS 23 paket programından yararlanılmıştır. Tanımlayıcı istatistikler için frekans, yüzde, aritmetik ortalama ve standart sapma; gruplar arasındaki farklılıkları test etmek için $t$ - testi ve tek yönlü varyans analizi (One Way Anova) ve değişkenler arasındaki ilişkileri saptamak için 'Pearson Momentler Çarpım Korelasyon Katsayısı' kullanılmıştır. Tek yönlü varyans analizinde gruplar arası farklılıkların hangi değişkenlerden kaynaklandığını test etmek için grup sayıları eşit ve birbirine yakın olanlarda Sheffe testi ve Tamhane T2; grup sayılarında farkl1lık olanlarda ise Gabriel ve Hochberg's GT2 ve Tamhane T2 (Field, 2013) Post Hoc testlerinden yararlanılmıştır. Son olarak da katılımcıların e-derslere yönelik memnuniyetlerinin öğretmen yenilikçiliğinin anlamlı bir yordayıcısı olup olmadığını test etmek için regresyon analizi yapılmıştır.

Analizlere başlamadan önce veriler kayıp değerler, uç değerler, normallik dağılımı, varyans homojenliği ve çoklu bağlantı varsayımları bakımından uygunluğu test edilmiştir. Verilerde kayıp değer ve uç değer bulunmamaktadır. E-öğrenme memnuniyet anketinin materyal, öğrenci öğretmen etkileşimi, öğrenme ortamı, tutum ve içerik boyutları ile öğretmen yenilikçiliği ölçeğinin çoklu bağlantı varsayımını karşılayıp karşılamadığını sınamak için yapılan doğrusal regresyon analiz çıtıları incelendiğinde Durbin Watson değeri 1.91, Varyans Büyütme Değerlerinin (VIF) 2.11 3.10 (Hair ve diğerleri, 2013) aralığında, CI değerlerinin 1.00-11 aralığında ve tolerans değerlerinin de oldukça yüksek (.447-.881) olduğu tespit edilmiştir. Ayrıca korelasyon ilişkileri analiz edildiğinde tüm değişkenlerin .80 'in altında bulunmuştur. Bu durum bağımsız değişkenler için çoklu bağlantı varsayımının karşılandığını göstermektedir. Varyans homojenliği testi için yapılan Levene istatistiği sonucunda $(\mathrm{p}>.05)$ iki değişken haricinde $(\mathrm{p}<.05)$ diğer değişkenlerin homojen olduğu görülmüştür. Varyansların homojenliği eşit olmadığ1 değişkenlerde Post-Hoc testlerden Sheffe testine ek olarak Tamhane T2, Gabriel ve Hochberg's GT2 testleri de sinanmıştır. Tamhane T2, Gabriel ve Hochberg's GT2 Post-Hoc testleri hücre boyutlarının eşit olmadığ1 ve/veya varyansların homojenliğinin ihlal edildiği durumlarda dikkatli karşılaş̧ırmalara olanak verebilen oldukça tutucu testler olarak kabul edilmektedir (De Muth, 2014; Field, 2013; Hochberg ve Tamhane, 1987). Normallik dağılımı için yapılan analizler sonucunda $t$ - testi ve tek yönlü varyans analizi için verilerin varyasyon katsayılarının kabul edilebilir aralıkta olduğu (\%18-25), skewness (-.423-.026) ve kurtosis (.445-.041) değerlerinin \pm 1 'in altında olduğu buna karşın, Kolmogorov Smirnov ve Shapiro-Wilk testlerinin ise anlamlı olduğu görülmüştür. Alanyazında, özellikle sosyal bilimlerde ve likert tipi ölçeklerde bu iki testin çok duyarlı olduğunu gösteren kanttlar bulunmaktadır (Tabachnick ve Fidell, 2013). Hair ve diğerleri (2013) ise bu durumlarda çarpıklık ve basıklık değerlerinin \pm 1 sinırları içinde olmasını, Tabachnick ve Fidell (2013) ise \pm 1.5 sınırları içinde olmasını normal dağılım için yeterli görmektedir. Ayrıca, normal dağılım varsayımının kabulünde yukarıda belirtilen tüm yöntemlerin birlikte değerlendirilmesi önerilmektedir (McKillup, 2012; Stevens, 2009). Dolayısıyla, verinin normal dağılım gösterdiği ve parametrik testler ile analiz edilmesi için uygun olduğu görülmüştür. 


\section{Bulgular}

Araştırmanın birinci alt probleminde katılımcıların pandemi sürecinde e-öğrenme uygulamalarına ve öğretmen yenilikçiliğine ilişkin görüşlerinin dağılımının nasıl olduğu araştırılmıştır. Katılımcıların e-ders/öğrenme uygulamalarına ve öğretmen yenilikçiliğine ilişkin ortalama puanları Tablo 2 ve Şekil 1'de verilmiştir.

Tablo 2: Katılımcıların e-öğrenme ile öğretmen yenilikçiliğine ilişkin görüşleri

\begin{tabular}{lcccccc} 
Değişkenler & $\mathrm{N}$ & $\overline{\mathrm{X}}$ & $\mathrm{SH}$ & $\mathrm{SS}$ & Çarpıklık & Basılklk \\
Materyal & 263 & 3.18 & .061 & .991 & -.423 & -.147 \\
Etkileşim & 263 & 3.38 & .062 & 1.01 & -.284 & -.417 \\
Öğgrenme ortamı & 263 & 3.33 & .052 & .847 & -.422 & .445 \\
Tutum & 263 & 3.23 & .046 & .751 & .026 & -.157 \\
İçerik & 263 & 3.31 & .045 & .737 & -.310 & .041 \\
E_öğrenme memnuniyeti & 263 & 3.28 & .044 & .729 & -.305 & .202 \\
Öğretmen yenilikçiliği & 263 & 3.32 & .062 & 1.00 & -.198 & -.280 \\
\hline
\end{tabular}

Not: SH: Standart hata; SS: Standart sapma

Tablo 2 ve Şekil 1'de e-öğrenme ve öğretmen yenilikçiliğine ilişkin öğrenci görüşleri incelendiğinde öğrencilerin genel e-öğrenme memnuniyetinin ( $\overline{\mathrm{X}}=3.28)$ "K1smen" [2.60-3.39] orta düzey aralığında olduğu görülmüştür. Alt boyut değişkenlerinde ise sirasıyla öğrenci öğretmen etkileşimi boyutu ( $\overline{\mathrm{X}}=3.38)$, öğrenme ortamı $(\overline{\mathrm{X}}=3.33)$, öğretmen yenilikçiliği $(\overline{\mathrm{X}}=3.32)$, içerik $(\overline{\mathrm{X}}=3.31)$ ve materyal boyutu ise $(\overline{\mathrm{X}}=3.18)$ bulunmuştur.

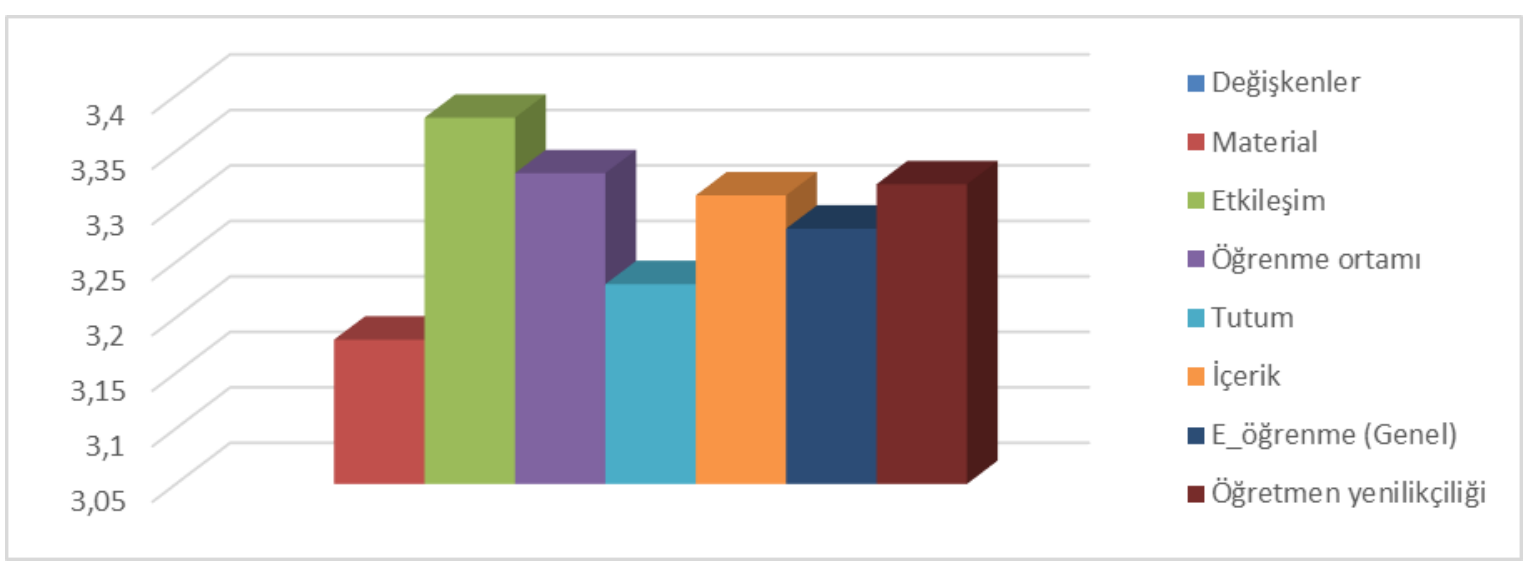

Şekil 1: Katılımcıların e-öğrenme ve öğretmen yenilikçiliğine ilişkin dağılımları

Alt boyutlardan en yüksek ortalama öğrenci öğretmen etkileşimi boyutunda gerçekleşmiştir ve bu boyut "katılıyorum" skalasına çok yakın bulunmuştur. Bu durum öğrencilerin öğrenme ortamına ve öğretmen yenilikçiliğine yönelik görüşleriyle de desteklenmektedir. Bununla birlikte, öğrencilerin e-öğrenme uygulamalarına dair en düşük ortalama e-ders materyallerine ilişkin görüşlerde ortaya çıkmıştır. Öğrencilerin e-derse ilişkin memnuniyetleri, öğretmenlerden istekdikleri zaman yanıt alabilmelerine, danışmanlık hizmetlerinin yeterliliğine, iletişimde sorun yaşamamalarına ve öğretim üyesinin düzenli olarak kendisini bilgilendirdirmesiyle ilişkili bulunmuştur. Öğretmen yenilikçiliğinin öğrencilerle kurulan iletişim, içerik, ders ortamı, materyal seçimi ve kullanımı değişkenleri ile etkileşimli olduğu söylenilebilir. Öğrencilerin e-ders uygulamalarına yönelik memnuniyet algıları bir bütün olarak değerlendirildiğinde benzer bir yap1 ortaya çıkmaktadır. Memnuniyet ölçeği toplam puanı dikkate alındığında e-derslere yönelik 
öğrenci memnuniyetinin "Kısmen katılıyorum" aralığında olduğu ve kararsız bir görünüm sergilediği görülmüştür.

Araştırmanın ikinci alt probleminde katılımcıların pandemi sürecinde e-öğrenme uygulamalarına ve öğretmen yenilikçiliğine ilişkin görüşlerinin cinsiyet, anne eğitim düzeyi, baba eğitim düzeyi değişkenlerine göre anlamlı bir fark gösterip göstermediği araştırılmıştır. Katılımcıların e-öğrenme uygulamalarına ve öğretmen yenilikçiliğine ilişkin görüşlerinin cinsiyet değişkenine göre anlamlı bir fark olup olmadığı Tablo 3 'te t-testi ile ortaya konulmuştur.

Tablo 3: Katılımcıların cinsiyet durumlarına ilişkin T-testi sonuçları

\begin{tabular}{|c|c|c|c|c|c|c|}
\hline \multirow{2}{*}{ Değişkenler } & \multicolumn{2}{|c|}{ Kadin $N=145$} & \multicolumn{2}{|c|}{ ErkekN=118 } & \multirow{2}{*}{$\mathrm{t}$} & \multirow{2}{*}{$p$} \\
\hline & $\overline{\mathrm{X}}$ & Ss & $\overline{\mathrm{X}}$ & Ss & & \\
\hline Teknolojiyi kullanmak derse karşı olan ilgimi arttırdı. & 2.84 & 1.33 & 3.24 & 1.168 & -2.53 & $.012^{*}$ \\
\hline Bu dersi e-ders olarak almaktan memnunum. & 2.85 & 1.423 & 3.29 & 1.228 & -2.65 & $.008^{*}$ \\
\hline Eğer fırsatım olsaydı bu dersi yüz yüze alırdım. & 4.02 & 1.172 & 3.71 & 1.199 & 2.15 & $.032^{*}$ \\
\hline Uzaktan eğitim beni daha çok motive etmektedir. & 2.68 & 1.450 & 3.22 & 1.275 & -3.11 & $.002^{*}$ \\
\hline E-öğrenme memnuniyeti & 3.17 & .792 & 3.41 & .617 & -2.59 & $.010^{*}$ \\
\hline Öğretmen yenilikçiliği & 3.25 & 1.09 & 3.41 & 0.88 & -1.27 & .203 \\
\hline
\end{tabular}

*Anlamlı fark düzeyi 0.05 .

Tablo 3 incelendiğinde, katılımcıların e-öğrenme uygulamalarına ilişkin tutum maddelerinden e-derse yönelik ilgi [ $\mathrm{t}(261)=-2.53, \mathrm{p}<.05]$ cinsiyete göre erkek katılımc1lar lehine $(\overline{\mathrm{X}}=3.24)$ anlamlı fark gösterdiği bulunmuştur. Dersi e-ders olarak alma memnununiyetine yönelik öğrenci görüşleri [t $(261)=-2.65, p<.05]$ cinsiyete göre erkek katılımcıların lehine $(\bar{X}=3.29)$ anlamlı bir farklılık gösterdiği tespit edilmiş̧ir. Dersi yüz yüze alma konusunda katılımcı görüsslerinin [ $\mathrm{t}(261)=2.15, \mathrm{p}<.05]$ cinsiyete göre kadın katılımcılar lehine $(\overline{\mathrm{X}}=4.02)$ anlamlı bir farkl11ık sergilediği görülmüştür. Uzaktan eğitimin öğrencileri motive etme düzeyine göre [t (261) $=-3.11, \mathrm{p}<.05]$ erkek öğrenciler lehine $(\overline{\mathrm{X}}=3.22)$ anlamlı bir farklılık gösterdiği bulunmuştur. Eöğrenme memnuniyetine yönelik katılımcı görüşleri [t $(261)=-2.59, \mathrm{p}<.05]$ cinsiyete göre erkek katılımcilar lehine $(\overline{\mathrm{X}}=3.41)$ anlamlı bir farklılık göstermektedir. Diğer taraftan, e-derslerde öğrencilerin öğretmen yenilikçiliği algısı [t $(261)=-1.27, \mathrm{p}>.05]$ cinsiyete göre anlamlı bir farklılık tespit edilmemiştir.

Tablo 4: Katılımcıların anne eğitim durumlarına ilişkin T-testi sonuçları

Değişkenler

Teknolojiyi kullanmak derse olan ilgimi arttırdı. $\mathrm{Bu}$ dersi e-ders olarak almaktan memnunum. Eğer firsatım olsaydı bu dersi yüz yüze alırdım. Uzaktan eğitim beni daha çok motive etmektedir. E-öğrenme memnuniyeti Öğretmen yenilikçiliği

\begin{tabular}{|c|c|c|c|c|c|}
\hline \multirow{2}{*}{\multicolumn{2}{|c|}{$\begin{array}{c}\text { Ortaokul ve alt1 } \\
N=132\end{array}$}} & \multicolumn{2}{|c|}{ Lise ve üstü } & \multirow{3}{*}{$\mathrm{t}$} & \multirow{3}{*}{$p$} \\
\hline & & \multicolumn{2}{|c|}{$\mathrm{N}=131$} & & \\
\hline$\overline{\mathrm{X}}$ & ss & $\overline{\mathrm{X}}$ & SS & & \\
\hline 2.86 & 1.28 & 3.19 & 1.25 & -2.09 & $.037^{*}$ \\
\hline 2.84 & 1.32 & 3.26 & 1.35 & -2.58 & $.010^{*}$ \\
\hline 3.93 & 1.27 & 3.83 & 1.11 & .626 & .532 \\
\hline 2.68 & 1.43 & 3.17 & 1.32 & -2.91 & $.004^{*}$ \\
\hline 3.17 & .746 & 3.39 & .692 & -2.54 & $.012^{*}$ \\
\hline 3.25 & 1.06 & 3.38 & .947 & -1.06 & .289 \\
\hline
\end{tabular}

*Anlamlı fark düzeyi 0.05 .

Tablo 4'e göre katılımcıların e-öğrenme uygulamalarına ilişkin tutumlarında e-derse yönelik ilgi $[\mathrm{t}(261)=-2.09, \mathrm{p}<.05]$ anne eğitim durumuna göre lise ve üstü katılımcılar lehine $(\overline{\mathrm{X}}=$ 3.19) anlamlı fark gösterdiği bulunmuştur. Dersi, e-ders olarak almaktan memnuniyet ise [t $(261)=$ $-2.58, \mathrm{p}<.05]$ anne eğitim durumuna göre annesi lise ve üzeri eğitim alan katılımcıların lehine $(\overline{\mathrm{X}}=$ 3.26) anlamlı bir farkl1lık gösterdiği tespit edilmiştir. Dersi yüz yüze alma isteği konusunda katılımcıların [t $(261)=.626, p>.05]$ anne eğitim durumuna göre katılımcıların görüşlerinde anlamlı bir farklılık tespit edilmemiştir. 'Uzaktan eğitim öğrencileri daha çok motive eder' maddesine yönelik öğrenci görüşleri ise [t $(261)=-2.91, \mathrm{p}<.05]$ anne eğitim durumu lise ve üstü olan katılımcılar lehine $(\overline{\mathrm{X}}=3.17)$ anlamlı bir farklılık gösterdiği tespit edilmiştir. E-öğrenme memnuniyetine yönelik katılımcı görüşleri $[\mathrm{t}(261)=-2.54, \mathrm{p}<.05]$ anne eğitim durumu lise ve 
üstü olan katılımcılar lehine $(\bar{X}=3.39)$ anlamlı bir farklılık göstermektedir. E-derslerde öğretmen yenilikçiliği boyutunda ise [ $\mathrm{t}(261)=-1.06, \mathrm{p}>.05]$ anne eğitim durumuna göre annesi ortaokul ve alt1, lise ve üstü eğitim alan katılımcıların görüssleri arasında anlamlı bir farklılık tespit edilmemiştir.

Tablo 5: Katılımcıların baba eğitim durumlarına ilişkin T-testi sonuçları

Değişkenler Ortaokul ve altı Lise ve üstü

Teknolojiyi kullanmak derse karşı olan ilgimi arttırdı.

$\mathrm{Bu}$ dersi e-ders olarak almaktan memnunum.

Eğer firsatım olsaydı bu dersi yüz yüze alırdım.

Uzaktan eğitim beni daha çok motive etmektedir.

E-öğrenme memnuniyeti

\begin{tabular}{|c|c|c|c|c|c|}
\hline \multicolumn{2}{|c|}{$\mathrm{N}=118$} & \multicolumn{2}{|c|}{$\mathrm{N}=145$} & \multirow[t]{2}{*}{$\mathrm{t}$} & \multirow{2}{*}{$p$} \\
\hline$\overline{\mathrm{X}}$ & Ss & $\overline{\mathrm{X}}$ & Ss & & \\
\hline 2.92 & 1.32 & 3.11 & 1.23 & -1.180 & .239 \\
\hline 3.03 & 1.39 & 3.07 & 1.33 & -.208 & .835 \\
\hline 3.84 & 1.24 & 3.93 & 1.15 & -.679 & .498 \\
\hline 2.89 & 1.47 & 2.95 & 1.34 & -.308 & .758 \\
\hline 3.22 & .678 & 3.34 & .762 & -1.372 & .171 \\
\hline 3.23 & .938 & 3.39 & 1.06 & -1.347 & .179 \\
\hline
\end{tabular}

Oğretmen yenilikçiliği
${ }^{*}$ Anlamlı fark düzeyi 0.05 .

Tablo 5 incelendiğinde katılımcıların e-öğrenme uygulamalarına ilișkin tutumlarında ederse yönelik ilgi [t (261) $=-1.180, \mathrm{p}>.05]$ baba eğitim durumuna göre babas1 ortaokul ve altı ile lise ve üstü eğitim alan katılımcıların görüşleri arasında anlamlı bir farklılık tespit edilmemiştir. Dersi, e-ders olarak almaktan memnuniyet ise [t $(261)=-.208 \mathrm{p}>.05]$ baba eğitim durumuna göre babası ortaokul ve altı ile lise ve üstü eğitim alan katılımcıların görüşleri arasında anlamlı bir farklılık sergilememektedir. Dersi yüz yüze alma isteği konusunda katılımcıların [t $(261)=-.679$, p>.05] baba eğitim durumuna göre katılımciların görüşlerinde anlamlı bir farkl1lık tespit edilmemiştir. Uzaktan eğitimin öğrencileri daha çok motive ettiğine yönelik bulgular ise [ $\mathrm{t}(261)=$ -308, p>.05] baba eğitim durumıuna göre katılımcıların görüşlerinde anlamlı bir farklılık göstermemektedir. E-öğrenme memnuniyeti toplam puanlarına yönelik katılımcı görüşleri $[\mathrm{t}(261)$ $=-1.372, \mathrm{p}>.05]$ baba eğitim durumuna göre anlamlı bir farkl1l1k göstermemektedir. E-derslerde öğretmen yenilikçiliği ise [ $\mathrm{t}(261)=-1.347, \mathrm{p}>.05]$ baba eğitim durumuna göre anlamlı bir farklılık tespit edilmemiştir.

Tablo 6: Katılımcıların aile gelir durumuna ilişkin ANOVA sonuçları

Değişkenler

$1^{*} \quad 2^{*} \quad 3^{*}$

\begin{tabular}{|c|c|c|c|c|c|c|c|c|}
\hline \multicolumn{2}{|c|}{$\mathrm{N}=37$} & \multicolumn{2}{|c|}{$\mathrm{N}=102$} & \multicolumn{2}{|c|}{$\mathrm{N}=124$} & \multirow{2}{*}{$\mathrm{F}$} & \multirow{2}{*}{$p$} & \multirow[t]{2}{*}{ Fark $^{* *}$} \\
\hline$\overline{\mathrm{X}}$ & SS & $\overline{\mathrm{X}}$ & SS & $\overline{\mathrm{X}}$ & SS & & & \\
\hline 2.76 & 1.38 & 3.03 & 1.20 & 3.10 & 1.29 & 1.06 & .34 & - \\
\hline 2.97 & 1.54 & 3.09 & 1.32 & 3.04 & 1.33 & .09 & .90 & - \\
\hline 3.62 & 1.44 & 3.96 & 1.16 & 3.90 & 1.13 & 1.12 & .32 & - \\
\hline 2.32 & 1.25 & 2.99 & 1.46 & 3.05 & 1.34 & 4.17 & $.016^{*}$ & $1<2$ ve 3 \\
\hline 3.21 & .776 & 3.21 & .642 & 3.36 & .77 & 1.53 & .21 & - \\
\hline 3.32 & 1.10 & 3.23 & .884 & 3.39 & 1.07 & .791 & .45 & - \\
\hline
\end{tabular}

Teknoloji kullanımı derse ilgimi arttırd1.

Dersi e-ders almaktan memnunum.

Fırsatım olsa dersi yüz yüze alırdım.

Uzaktan eğitim beni motive eder.

E-öğrenme memnuniyeti

$1^{*}$ : Üç bin liranın altında geliri olanlar; $2^{*}$ : Üç binden altı bin liraya kadar geliri olanlar; $3^{*}$ : Altı bin ve üzeri geliri olanlar. ${ }^{* *}$ Post-Hoc testleri olarak Sheffe, Tamhane T2, Gabriel ve Hochberg's testleri kullanılmış olup her üç testte de ilgili gruplar arasında anlamlı fark bulunmuştur. Tabloda gösterilen $p$ değeri Sheffe testi değeridir.

Araştırmanın üçüncü alt probleminde katılımcıların pandemi sürecinde e-öğrenme uygulamalarına ve öğretmen yenilikçiliğine ilişkin görüşlerinin aile gelir durumuna, katılımcıların okuduğu bölüme ve ders amaçlı haftada kaç saat internet kullandıkları değişkenlerine göre anlamlı bir fark gösterip göstermediği araştırılmıştır. Katılımcıların e-öğrenme uygulamalarına ve öğretmen yenilikçiliğine ilişkin görüşlerinin aile gelir durumuna göre anlamlı bir fark olup olmadığı Tablo 6’da tek yönlü varyans analizi (One way Anova) ile ortaya konulmuştur. 
Tablo 6 incelendiğinde, katılımcıların sadece 'uzaktan eğitimin kendilerini motive ettiği' maddesi ile aile gelir durumu arasında anlamlı farklılık $[\mathrm{F}(3,260)=4.17, \mathrm{p}<.05]$ bulunmuştur. Anlamlı farklılığın hangi gruplar arasında olduğunu test etmek için yapılan Post-Hoc test sonuçlarına göre öğrenci ailesinin gelir durumu 'üç bin liranın altında olanlar' ( $\overline{\mathrm{X}}=2.32)$ ile 'üç binden altı bin liraya kadar geliri olanlar' $(\overline{\mathrm{X}}=2.99)$ ve 'altı bin ve üzeri geliri olanlar' $(\overline{\mathrm{X}}=3.05)$ arasında anlamlı farklılık olduğu bulgusuna ulaşılmıştır. Katılımcıların e-öğrenme uygulamalarına ve öğretmen yenilikçiliğine ilişkin görüşlerinin öğrenim gördüğü bölüme göre anlamlı bir fark olup olmadı $\breve{g} 1$ Tablo 7'de verilmiştir.

Tablo 7: Katılımcıların okuduğu bölüme ilişkin ANOVA sonuçları

\begin{tabular}{|c|c|c|c|c|c|c|c|c|c|c|c|}
\hline \multirow{3}{*}{ Değişkenler } & \multirow{2}{*}{\multicolumn{2}{|c|}{$\begin{array}{c}1^{*} \\
\mathrm{~N}=88\end{array}$}} & \multirow{2}{*}{\multicolumn{2}{|c|}{$\begin{array}{c}2^{*} \\
\mathrm{~N}=51\end{array}$}} & \multirow{2}{*}{\multicolumn{2}{|c|}{$\begin{array}{c}3^{*} \\
\mathrm{~N}=45\end{array}$}} & \multirow{2}{*}{\multicolumn{2}{|c|}{$\begin{array}{c}4^{*} \\
\mathrm{~N}=79\end{array}$}} & \multirow{3}{*}{$\mathrm{F}$} & \multirow{3}{*}{$p$} & \multirow{3}{*}{ Fark ${ }^{* *}$} \\
\hline & & & & & & & & & & & \\
\hline & $\overline{\mathrm{X}}$ & SS & $\overline{\mathrm{X}}$ & Ss & $\overline{\mathrm{X}}$ & ss & $\overline{\mathrm{X}}$ & Ss & & & \\
\hline Teknoloji kullanımı & 2.75 & 1.28 & 2.84 & 1.25 & 3.64 & 1.06 & 3.10 & 1.27 & 5.61 & $.001^{*}$ & 1 ve $2<3$ \\
\hline E-ders alma & 2.72 & 1.42 & 2.92 & 1.368 & 3.68 & .874 & 3.13 & 1.38 & 5.53 & $.001^{*}$ & 1 ve $2<3$ \\
\hline \multirow{2}{*}{$\begin{array}{l}\text { Yüz yüze eğitim } \\
\text { Uzaktan eğitim } \\
\text { motivasyon }\end{array}$} & 3.92 & 1.22 & 3.88 & 1.25 & 3.44 & 1.32 & 4.10 & .968 & 3.00 & $.031^{*}$ & \multirow{2}{*}{$\begin{array}{c}3<4 \\
1 \text { ve } 2<3\end{array}$} \\
\hline & 2.64 & 1.43 & 2.50 & 1.25 & 3.66 & 1.16 & 3.08 & 1.39 & 7.80 & $.000^{*}$ & \\
\hline $\begin{array}{l}\text { E-öğrenme } \\
\text { memnuniyeti }\end{array}$ & 3.11 & .791 & 3.04 & .812 & 3.62 & .564 & 3.43 & .564 & 8.37 & $.000^{*}$ & $1,2,4<3$ \\
\hline Öğretm. yenilikçiliği & 3.23 & 1.13 & 3.08 & .993 & 3.58 & .892 & 3.41 & .887 & 2.48 & .061 & - \\
\hline
\end{tabular}

1*: İngilizce öğretmenliği; 2*: Psikolojik Danışma ve Rehberlik; 3*: Bilişm teknolojileri öğretmenliği; 4*: Türkçe, Ana sınıf ve Sınıf öğretmenliği. ${ }^{* *}$ Post-Hoc testleri olarak Sheffe, Tamhane T2, Gabriel ve Hochberg's kullanılmış ve gruplar arasında benzer anlamlı fark bulunmuştur. $p$ değeri Sheffe değeridir.

Tablo 7'ye göre, katılımcıların ‘teknoloji kullanımı derse yönelik ilgimi artırdı' maddesi ile öğrenim gördüğü bölüm arasında anlamlı farkl1lık $[\mathrm{F}(4,259)=5.61, \mathrm{p}<.05]$ bulunmuştur. $\mathrm{Bu}$ farkl11ık, bilişim teknolojileri bölümü öğrencileri lehine $(\overline{\mathrm{X}}=3.64)$, psikolojik danışma ve rehberlik bölümü $(\overline{\mathrm{X}}=2.84)$ ve İngilizce öğretmenliği bölümü $(\overline{\mathrm{X}}=2.75)$ öğrencileri arasındadır. Benzer şekilde e-derslere ilişkin memnuniyetle katılımcıların öğrenim gördüğü bölüm arasında anlamlı farkl1lık $[\mathrm{F}(4,259)=5.53, \mathrm{p}<.05]$ bulunmuştur. $\mathrm{Bu}$ farklılık bilişim teknolojileri bölümü öğrencileri lehine $(\bar{X}=3.68)$, psikolojik danışma ve rehberlik bölümü $(\bar{X}=2.92)$ ve İngilizce öğretmenliği bölümü $(\bar{X}=2.72)$ öğrencileri arasında tespit edilmiştir. Dersi yüz yüze almaya ilişkin görüşler ile katılımcıların öğrenim gördügü bölüm arasında da anlamlı bir farklılık $[F(4,259)=$ $3.00, \mathrm{p}<.05$ ] bulunmuştur. Anlamlı farklılığın hangi gruplar arasında olduğunu test etmek için yapılan Post-Hoc test sonuçlarına göre bilişim teknolojileri öğretmenliği bölümü öğrencileri $(\overline{\mathrm{X}}=$ 3.44) Türkçe, anasınıfı ve sınıf öğretmenliği bölümü öğrencilerinden $(\bar{X}=4.10)$ daha az yüz yüze öğrenim görmek istemektedirler. E- derslerin öğrencileri daha çok motive ettiğine yönelik bulgular katılımcıların öğrenim gördüğ̈̈ bölüme göre de anlamlı bir farkl1lık $[F(4,259)=7.80, p<.05]$ sergilemektedir. Bu farklılık, bilişim teknolojileri lehine $(\overline{\mathrm{X}}=3.66)$, psikolojik danışma ve rehberlik bölümü $(\overline{\mathrm{X}}=2.50)$ ve İngilizce öğretmenliği bölümü $(\overline{\mathrm{X}}=2.64)$ öğrencileri arasında bulunmuştur. Öğrencilerin e-öğrenmeye yönelik genel memnuniyetleri ile öğrenim görülen bölüm arasında anlamlı bir farklılık $[\mathrm{F}(4,259)=8.37, \mathrm{p}<.05]$ tespit edilmiştir. $\mathrm{Bu}$ anlamlı farklılık, bilişim teknolojileri bölümü öğrencileri lehine $(\overline{\mathrm{X}}=3.62)$, psikolojik danışma ve rehberlik bölümü $(\overline{\mathrm{X}}=$ 3.04), İngilizce öğretmenliği bölümü $(\bar{X}=3.11)$ ve Türkçe, anasınıfı ve sınıf öğretmenliği bölümü $(\overline{\mathrm{X}}=3.43)$ öğrencileri arasındadır. Buna karşın, öğretmen yenilikçiliği ile öğrenim görülen bölüm arasında anlamlı bir farkl11ı $[\mathrm{F}(4,259)=2.48, \mathrm{p}<.05]$ tespit edilememiştir.

Araştırmada ele alınan diğer bir değişken ise katılımcıların ders amaçlı internet kullanım durumları ile derse olan ilgi, e-ders memnuniyeti, dersi yüz yüze alma isteği, e-ders motivasyonu, genel öğrenme memnuniyeti ve öğretmen yenilikçiliği arasında anlamlı fark olup olmadığı Tablo 8 'de verilmiştir. 
Tablo 8: Ders amaçlı haftalık internet kullanımına ilişkin ANOVA sonuçları

\begin{tabular}{|c|c|c|c|c|c|c|c|c|c|c|c|}
\hline \multirow{3}{*}{ Değişkenler } & \multirow{2}{*}{\multicolumn{2}{|c|}{$\begin{array}{c}1^{*} \\
\mathrm{~N}=46\end{array}$}} & \multirow{2}{*}{\multicolumn{2}{|c|}{$\begin{array}{c}2^{*} \\
\mathrm{~N}=85\end{array}$}} & \multirow{2}{*}{\multicolumn{2}{|c|}{$\begin{array}{c}3^{*} \\
\mathrm{~N}=80\end{array}$}} & \multirow{2}{*}{\multicolumn{2}{|c|}{$\begin{array}{c}4^{*} \\
\mathrm{~N}=52\end{array}$}} & \multirow{3}{*}{$\mathrm{F}$} & \multirow{3}{*}{$p$} & \multirow{3}{*}{$\underset{* *}{\text { Fark }}$} \\
\hline & & & & & & & & & & & \\
\hline & $\overline{\mathrm{X}}$ & SS & $\overline{\mathrm{X}}$ & ss & $\overline{\mathrm{X}}$ & Ss & $\overline{\mathrm{X}}$ & ss & & & \\
\hline \multirow{4}{*}{$\begin{array}{l}\text { Teknoloji kullanımı } \\
\text { E-ders alma } \\
\text { Yüz yüze eğitim } \\
\text { Uzaktan eğitim } \\
\text { motivasyon }\end{array}$} & 2.58 & 1.42 & 3.00 & 1.17 & 3.07 & 1.29 & 3.38 & 1.19 & 3.32 & .02 & \multirow{4}{*}{$\begin{array}{c}1<4 \\
- \\
1<3,4 \\
-\end{array}$} \\
\hline & 2.93 & 1.48 & 3.00 & 1.30 & 3.08 & 1.37 & 3.19 & 1.32 & .358 & .78 & \\
\hline & 3.52 & 1.41 & 3.72 & 1.23 & 4.10 & 1.09 & 4.13 & .929 & 3.63 & .01 & \\
\hline & 2.67 & 1.30 & 2.87 & 1.36 & 3.00 & 1.44 & 3.13 & 1.46 & 1.005 & .39 & \\
\hline E-öğrenme memnuniyeti & 2.98 & .780 & 3.18 & .642 & 3.34 & .766 & 3.62 & .607 & 7.685 & .00 & $1<4$ \\
\hline Öğretm. yenilikçiliği & 3.04 & 1.19 & 3.23 & .924 & 3.47 & .976 & 3.45 & .960 & 2.313 & .07 & - \\
\hline
\end{tabular}

$1^{*}$ : Üç saatten daha az; 2*: Beş saate kadar $3^{*}$ : Dokuz saate kadar; 4*: Dokuz saat ve üstü. . ${ }^{* *}$ Post-Hoc testleri olarak Sheffe, Tamhane T2, Gabriel ve Hochberg's testleri kullanılmış olup her üç testte de ilgili gruplar arasında anlamlı fark bulunmuştur. Tabloda gösterilen $p$ değeri Sheffe testi değeridir.

Tablo 8 incelendiğinde katılımcıların 'teknoloji kullanımının derse yönelik ilgimi artırdı' maddesi ile katılımcıların eğitim amaçlı haftalık internet kullanım miktarı arasında anlamlı farklılık $[\mathrm{F}(4,259)=3.32, \mathrm{p}<.05]$ 'dokuz saat ve üstü' ders amaçlı bilgisayar kullananlar lehine 'üç saatten az' kullananlar arasında olduğu bulgusuna ulaşılmıştır. Dersi e-ders olarak almaya ilişkin memnuniyet $[F(4,259)=5.358, p>.05]$, 'uzaktan eğitim beni motive eder' $[F(4,259)=1.005, p$ $>$.05] yönelik katılımcıların görüşleri ile ders amaçlı haftalık internet kullanım miktarı arasında anlamlı bir farklılık tespit edilememiştir. Benzer şekilde 'öğretmen yenilikçiliği' boyutu ile öğrencilerin ders amaçlı haftalık internet kullanım miktarı arasında da anlamlı bir farklılık [F (4, $259)=2.313, \mathrm{p}<.05$ ] tespit edilememiştir. Buna karşın, 'dersi yüz yüze almaya' ilişkin katılımcı görüşleri ile katılımcıların ders amaçlı haftalık internet kullanım saati arasında da ders amaçlı altı ve üzeri saat kullanan son iki grup arasında anlamlı bir farklılık $[\mathrm{F}(4,259)=3.63, \mathrm{p}<.05]$ bulunmuştur. Son olarak, e-öğrenme memnuniyetine yönelik genel görüşler ile katılımcıların eğitim amaçlı haftalık internet kullanım miktarı arasında $[\mathrm{F}(4,259)=8.37, \mathrm{p}<.05]$ ders amaçlı haftada 'dokuz saat ve üzeri' kullanan öğrenciler lehine 'üç saatten az kullanan öğrencilere göre anlamlı bir farklılık tespit edilmiştir.

Araştırmanın dördüncü alt probleminde katılımcıların e-ders memnuniyetleri ile öğretmen yenilikçiliği ve internet kullanımı değişkenleri arasındaki ilişkiler araştırılmıştır. Katılımcıların eders memnuniyetleri ile ilişkili bazı değişkenlere ait bulgular Tablo 9'da Pearson korelasyon analizi ile ortaya konulmuştur.

Tablo 9: E-ders memnuniyeti, ders amaçlı internet kullanımı ve öğretmen yeniliçiliğine ilişkin Pearson korelasyon analizi

\begin{tabular}{lccc}
\hline Değişkenler & 1 & 2 & 3 \\
1. İternet kullanımı & - & & \\
2. Öğretmen yenilikçiliği &, $149^{*}$ & - & \\
3. E-öğrenme memnuniyeti &, $283^{* *}$ &, $699^{* *}$ & - \\
\hline${ }^{* *} \cdot p<0.01$ level. ${ }^{*} \cdot p<.0 .05$ level. & &
\end{tabular}

Katılımcıların e-öğrenme memnuniyetleri ile ders amaçlı internet kullanımı ve öğretmen yenilikçiliği arasındaki ilişki Tablo 9'de verilmiştir. Üniversite öğrencilerinin e-öğrenme memnuniyetleri ile öğretmen yenilikçiliği arasında pozitif yönlü yüksek düzeyde $(r=.699, \mathrm{p}<.01)$; internet kullanımı arasında ise düşük anlamlı ilişkiler $(\mathrm{r}=.283, \mathrm{p}<.01)$ tespit edilmiştir. Üniversite öğrencilerinin öğretmen yenilikçiliği algıları ile internet kullanımı $(\mathrm{r}=.149, \mathrm{p}<.05)$ arasında çok düşük düzeyde anlamlı ilişkiler tespit edilmiştir. 
Araştırmanın beşinci alt probleminde pandemi sürecinde katılımc1ların öğretmen yenilikçiliğinin algılarının e-öğrenme memnuniyetinin anlamlı bir yordayıcısı olup olmadığı regresyon analizi ile Tablo 10'da ortaya konulmuştur.

Tablo 10: Üniversite öğrencilerinin öğretmen yenilikçiliği algılarının e-ders memnuniyetlerine etkisini inceleyen regresyon analizi sonuçları

\begin{tabular}{lccccccccc}
\hline \multirow{2}{*}{ Değişkenler } & \multicolumn{10}{c}{ Öğretmen yenilikçiliği } \\
\cline { 2 - 10 } E-öğrenme memnuniyeti & $\mathrm{N}$ & Sabit & $\mathrm{R}$ & $\mathrm{R}^{2}$ & $\mathrm{~F}$ & $\beta^{*}$ & $\mathrm{t}$ & $p$ & $\mathrm{DW}^{* *}$ \\
\cline { 2 - 10 } & 263 & 1.605 & .699 & .489 & 249.490 & .505 & 15.795 & $.000^{*}$ & 1.256 \\
\hline
\end{tabular}

Yordayıcı: öğretmen yenilikçiliği, $\mathrm{p}<.05 ; \beta^{*}$ : standardize edilmemiş değer, (standart $\beta . .699$ ); DW**: Durbin Watson değeri.

Tablo 10 incelendiğinde, katılımcı görüşlerine göre öğretmen yenilikçiliğinin $(R=.699, p$ $<.05)$ e-öğrenme memnuniyetinin anlamlı bir yordayıcısı $(\beta=.51, \mathrm{p}<.05)$ olduğu görülmüştür. $\mathrm{Bu}$ bulgular 1şı̆̆ında öğretmen yenilikçiliği davranışlarına paralel olarak öğrencilerin eders/öğrenmeye karşı memnuniyet düzeylerinin de olumlu yönde artış gösterdiği söylenebilir.

\section{Tartışma ve Sonuç}

Bu çalışmada, 2020 yılında ortaya çıkan ve bütün dünyayı etkisi altına alan Covid-19 pandemi sürecinde yapılan e-derslerin öğrencilerin perpektifinden memnuniyet durumu araştırılmıştır ve öğretmen yenilikçiliğinin öğrencilerin e-derse yönelik memnuniyet durumlarını yordama düzeyi değerlendirilmiştir. Bu amaçla, çalışmada e-ders ile uzaktan eğitim alan üniversite öğrencilerinin uzaktan eğitim uygulamalarına, öğretmen yenilikçiliğine, teknoloji kullanımına, yüz yüze eğitime ve ders motivasyonuna ilişkin görüşlerinin cinsiyete, anne ve baba eğitim düzeyine, aile gelir durumuna, katılımcıların okuduğu bölüme ve ders amaçlı haftada kaç saat internet kullandıkları değişkenlerine göre farklılık düzeyleri ile bu değişkenler arasındaki ilişkiler de araştırılmıştır.

Araştırmanın birinci alt probleminde pandemi sürecinde öğrencilere sunulan uzaktan eğitim derslerinin öğrenciler tarafindan orta düzeyde memnuniyetle karşılandığı sonucuna ulaşılmıştır. Öğrenci menuniyeti alt boyutlarına ilişkin öğrenci algıları hemen hemen birbirlerine yakın ortalamalar içermektedir. Bu sonuçlar, Kim ve Frick (2011)'in çevrim içi öğrenme sürecinde öğrenci motivasyonunu araştırdığı çalışma bulguları ile benzerlik göstermektedir. Ayrıca, araştırmada ortaya konulan e-derslere yönelik ilgi, memnuniyet ve motivasyonun Dai ve Xia (2020)'in araştırma sonuçları ile benzerlik göstermektedir. Dai ve Xia (2020)'in çalışmasında Çin'de uygulanan "School is Out, but Class is On" mottosuyla hayata geçirilen öğretim çevrelerinin öğrencilerin bağımsız bir şekilde öğrenme becerilerine katkıda bulunduğu, okulun bireyselleştirilmiş öğrenme kaynakları ile kendi kendine geliştirdiği e-öğrenme platformunun öğrencilerin akademik performanslarını önemli ölçüde artırdığını belirtmişlerdir.

Öğrencilerin e-öğrenme uygulamalarına dair en düşük ortalama e-ders materyallerine ilişkin görüşlerde ortaya çıkmıştır. Bu durum, öğretim görevlilerinin e-derslere ilişkin kullandıkları e-ders materyallerinin, yöntem ve tekniklerinin, sunum şekillerinin öğrencilerin daha az ilgisini çektiği şeklinde de yorumlanabilir. Paechter ve Maier (2010)'in Avusturyalı öğrencilerin çevirimiçi veya yüz yüze öğrenmelerden hangisini tercih ettikleri hakkındaki çalışmasında belirgin bir öğrenme materyali sunulduğunda çevirim-içi öğrenmeleri tercih ettiklerini, ortak bir anlayışın çıarılması gereken hedefler için ise yüz yüze eğitimi tercih ettikleri belirtilmektedir. Celen ve diğerleri (2018) ise çevrim-içi eğitimde sunulan ders materyallerinin öğrenenlerin pasif ekran izleyicileri olmaktan kurtaran şekilde tasarlanması gerektiğine vurgu yapmaktadır. Diğer taraftan, araştırmada en yüksek ortalama öğrenci öğretmen etkileşimi boyutunda gerçekleşmiştir. Bu boyut 'katılıyorum' skalasının hemen alt sınırında yer almaktadır. Öğrenci öğretmen etkileşimi öğrenmeöğretme sürecinin en önemli bileşenlerinden birisidir. Eğitim kalitesinin de temel belirleyicilerindendir (Atasoy \& Cemaloğlu, 2018; Celen ve diğerleri, 2018). Eğitim-öğretim 
süreçlerinde öğrenci öğretmen etkileşimi çevirim-içi öğrenmenin kalıc1lığı ve sürdürülebilirliği (Atıcı, 2004) açısından da anahtar bir kavramdır.

Eğitim öğretim süreçlerinde öğrenci öğretmen etkileşimini artırmada öğretmen yenilikçiliği önemli bir rol oynar. Öğretmen yenilikçiliği çevirim-içi e-derslerin kalitesini öne çıkarmaktadır. Öğretmen yenilikçiliği, değişime ve yeni fikirlere açıklık, poblem çözme ve işbirliği bağlamında ele alınmaktadır ve öğrenci memnuniyetinde çevirim-içi e-derslerin niteliğini değiştirmede ve geliştirmede etkili olabilmektedir. Yeniliklere ve değişime açık bir öğretim görevlisi uhdesine verilen derslerin içeriklerini geliştirmede, yeni yöntem, teknik ve materyaller kullanmada, olası problemleri çözmede, meslektaşları ve ilgili diğer paydaşlarla işbirliği kurmada etkili olur. Öğretmen yenilikçiliğinin öğrencilerle kurulan iletişimle, içerik geliştirmeyle, ders ortamının düzenlenmesiyle, materyal seçimi ve kullanımının etkileşimiyle iç içe olduğuna dair ipuçları vermektedir. Yenilikçi öğretmen niteliklerinin işe koşulması sonucu öğrenme-öğretme süreçlerinin kalitesi yükselir ve bu durum ögrencilerin ilgi, motivasyon ve memnuniyet düzeylerine olumlu yönde etki yapar. Diğer taraftan, geleneksel öğrenme yöntemlerinin günümüz öğrenci kuşağının motive etmede yetersiz kaldığı (Suanpang ve diğerleri, 2004) ve bu kuşağın bilişim teknolojileri içine doğduğu gözden kaçırılmaması gereken bir durumdur. Lin ve diğerleri (2014) bu bağlamda eöğrenme stratejilerinin geleneksel öğrenme metodlarından öğrenme motivasyonu bakımından daha üstün nitelikler barındırdığını ortaya koymaktadır. Yenilikçi öğretmenler uzaktan eğitim uygulamalarında geleneksel öğretmenlerden farklı bir duruş sergilediğini gösteren kanıtlar bulunmaktadır. Bu bağlamda çevirim-içi öğrenmenin başarısı ilgili öğrenme ortamlarının yenilikçi bir yaklaşımla ele alınması önemlidir. Ayrıca, öğretmenlerin uzaktan öğrenmeye yönelik ilgi ve yeterliliklerinin geliştirilmesi öncelikli politika hedefleri arasında olabilir. Nitekim Covid-19 pandemisi ile öne çıkan uzaktan eğitim uygulamalarına yönelik ilginin düşük olduğunu gösteren araştırmalar bulunmaktadır (Celen ve diğerleri, 2018; Özkok, 2009; Turan \& Çolakoğlu, 2008).

Araştırmanın ikinci alt probleminde e-öğrenme uygulamalarına ilişkin öğrenci memnuniyetlerinin ve öğretmen yenilikçiliğinin cinsiyet, anne ve baba eğitim düzeyi değişkenleri açısından değerlendirilmesi yapılmıştır. Araştırmada erkek öğrencilerin bilgisayar destekli uzaktan öğrenme ders etkinliklerine yönelik ilgi, memnuniyet ve motivasyon açısından kadın katılımcılara göre anlamlı düzeyde farklılaştığı sonucuna ulaşılmıştır. Buna karşın, yüz yüze öğrenmeyi tercih etme konusunda kadın katılımcılar anlamlı bir şekilde ayrıştığı görülmüştür. Bu sonuçlar kadın katılımcıların e-ders uygulamalarına yönelik daha az memnun oldukları şeklinde de yorumlanabilir. Bilgisayar teknolojileri ve bilgisayar destekli öğrenme platformlarıla etkileşime girememenin derse ilgiyi azaltacağını ve öğrencilerin konu dışı eylemlere yönelmelerine neden olacă̆ını gösteren kanıtlar (Al \& Madran, 2004; Dinçer \& Yeşilpınar, 2016; Liu, 2013; Pirnary-Dummer ve diğerleri, 2010) bu durumu desteklemektedir. Bununla birlikte her iki grup ortalama puanlarında yüz yüze eğitim alma isteğinin e-ders olarak alma tercihinden daha yüksek olmasının detaylı bir şekilde araştırılması gerekmektedir.

Katılımcıların anne eğitim düzeyi lise ve üstü olanların e-derse yönelik ilgi, memnuniyet ve motivasyonları da anne eğitim düzeyi ortaokul ve altı olan katılımcılara göre daha yüksek bulunmuştur. Buna karşın, katılımcıların baba eğitim düzeylerine göre anlamlı bir farklılık bulunamamıştır. Anne ve baba eğitim durumlarında öğrencilerin eğitim hayatları ve eğitime bakış açılarında anne rolünün babalarınkinden daha baskın olduğu görülmektedir. Sosyoekonomik bağlam birçok ulusal ve PISA, TIMSS ve PIAAC gibi uluslararası değerlendirmelerde yaygın olarak kullanılan endikatörlerdendir. $\mathrm{Bu}$ bağlam, öğrenci hazırbulunuşluğunu, bireyin eğitim olanaklarından optimum düzeyde yararlanabilmesinin önündeki engelleri anlamada kavramsal bir çerçeve sunar. Bunlardan, Atasoy ve Güçlü (2019); Karabay (2013); Karabay ve diğerleri (2015) ve Özer ve Anıl (2011) ebeveyn faktörünün özellikle de anne eğitim durumunun eğitim firsatlarına ulaşmada belirleyici olduğuna vurgu yaptıkları görülmüştür. Berge (2013) araştırmasında uzaktan öğrenmeleri kısıtlayan engeller arasında kültürel ve sosyal mesafenin etkili olduğuna dikkat 
çekmektedir. Öğrencinin içinde yetiştiği aile ortamı, onların eğitim düzeyleri ve ebeveyn-öğrenci etkileşimleri öğrencilerin ileriki öğrenme tercihlerinde etkili olabilmektedir.

Araştırmanın üçüncü alt probleminde katılımcıların pandemi sürecinde e-öğrenme uygulamalarına ve öğretmen yenilikçiliğine ilişkin görüşlerinin aile gelir durumuna, katılımcıların okuduğu bölüme ve ders amaçlı haftada kaç saat internet kullandıkları değişkenler açısından değerlendirilmesi yapılmıştır. Düşük gelir grubuna dâhil ailelerden gelen katılımcıların e-ders etkinliklerine ilişkin motivasyonları görece daha yüksek gelirli aileden gelen katılımcılara göre daha düşük bulunmuştur. Aile gelir durumu yükseldikçe e-derslere yönelik motivasyonun yükselmesi e-öğrenme sistemlerinin gerektirdiği cihazlara ve internet kullanım maliyetlerine ulaşmadaki kolaylıklardan kaynaklandığ 1 düşünülebilir. Mailizar ve diğerleri (2020) ve Muilenburg ve Berge (2005) de öğrencilerin çevirim-içi eğitim platformlarını kullanabilmek için öğrencilerin internet bağlantılarına ve e-öğrenme de kullanacak cihazlara sahip olmamaları ya da akranlarına göre daha ileri yaşlarda ulaşabilmelerinin de e-derse yönelik tutum ve başarılarını etkileyebildiğinin altını çizmektedir. Margarida ve Federico (2017) ise sosyo ekonomik bakımdan dezavantajlı grupların dijital teknolojilerden daha fazla yararlanılması için kullanılacak cihaz, öğrenen becerileri, sosyal destek, motivasyon, tutum gibi çok boyutlu bir yaklaşımla durumun ele alınmasının gerekliliğine işaret etmektedir. Ancak bu konuda daha çok destekleyici kanıtlara gereksinim bulunmaktadır.

Araştırma sonuçlarına göre, e-öğrenme ya da yüz yüze eğitimin tercih edilmesi öğrenim görülen bölüme ve internet kullanım düzeyine göre de değişikilik göstermektedir. Bilişim teknolojileri bölümü öğrencilerinin derse ilgi ve memnuniyetlerinin, ingilizce öğretmenliği, psikolojik danışma ve rehberlik öğretmenliği bölümlerinin öğrencilerinden daha fazla olması bilgisayar kullanımına daha çok aşina olmalarından ve proje, ödev, sınav gibi etkinlikleri internet üzerinden kolayca yapabilmelerinden kaynaklandığı söylenebilir. Diğer bir ifade ile, bilişim teknolojileri bölümü öğrencilerinin diğer bölüm öğrencilerinden anlamlı düzeyde bir farklılık göstermesi bu bölüm öğrencilerinin bilişim teknolojileri alt yapısına ve BİT teknolojilerini kullanma becerilerinin daha yüksek olmasına ve diğer bölüm öğrencilerinden daha donanımlı olmalarından kaynaklandığı düşünülmektedir. Buna karşın, Türkçe, ana sınıfı ve sınıf öğretmenliği bölümlerinde öğrenim gören öğrencilerin yüz yüze öğrenim görmeyi tercih etmeleri dikkat çekici bulunmuştur. Türkçe, ana sınıfı ve sınıf öğretmenliği bölümleri ders programları, hedef kitleleri, hedef kitlenin yaş grubu, hedef kitlenin türe özgü öğrenmeye hazır bulunuşluk hali, kullanılan ders materyalleri, iletişim kanallarının farklılı̆̆ sebepleri ile doğrudan yüz yüze eğitime dayalı bir yapı sergilemektedir. Bu bölüm öğrencilerinin yüz yüze eğitimi daha fazla tercih etmelerini kendi dinamikleri içerisinde değerlendirmekte fayda vardır. Benzer şekilde, ders amaçlı haftalık internet kullanımı daha yüksek olanların diğer gruplara göre e-derse olan ilgilerinin ve memnuniyetlerinin yüksek olduğu sonucuna ulaşılmıştır. Ancak, bireylerin teknoloji yoğun ortamlarda problem çözme beceri performanslarını (TYOPÇB) indirgemeci bir yaklaşımla sadece bilgisayarlara erişim ve yüksek hızlı bağlantıya sahip olmakla ilişkilendirmek de hatalı yorumlamalara sebep olabilir (Atasoy \& Çoban, 2020; Sweets \& Meates, 2004). Atasoy ve Çoban, (2020) TYOPÇB bireylerin yaşlarına, sosyoekonomik statülerine, kendi ve ebeveynlerinin eğitim geçmişlerine, öğrenme stratejilerine, bilgisayarları kullanım amaçlarına göre de değişkenlik gösterebildiğine vurgu yapmaktadır.

Araştırmanın dördüncü ve beşinci alt problemlerinde katılımcıların e-ders memnuniyetleri ile öğretmen yenilikçiliği değişkenleri arasındaki ilişkiler araştırılmıştır. Üniversite öğrencilerinin e-öğrenme memnuniyetleri ile öğretmen yenilikçiliği arasında pozitif yönlü yüksek düzeyde anlamlı ilişkiler bulunmuştur. Öğretmen yenilikçiliğinin e-öğrenme memnuniyetinin anlamlı bir yordayıcısı olduğu sonucuna ulaşılmıştır. Bu bulgular ışığında öğretmen yenilikçiliği davranışlarına paralel olarak öğrencilerin e-ders/öğrenmeye karşı memnuniyet düzeyleri de olumlu yönde artış gösterdiği söylenebilir. Cheng (2012) e-öğrenme ortamlarında öğretmenin anahtar bir rol oynadığını, öğretmenin sağladığı birçok öğrenme firsatlarıyla e-öğrenmeye ilişkin öğrenci 
doyumunun öğretmen nitelikleriyle doğrudan ilgili olduğunu belirtmektedir. Al-Fraihat ve diğerleri (2020)'nin araştırmasında da e-ders sistemine yönelik algılanan kullanışlılık, algılanan doyum, öğretmen kalitesi, sistem kalitesi, bilgi kalitesi ve öğretim ortamı gibi unsurların etkili olduğu sonucuna ulaşılmıştır. Araştırmamızla benzerlik gösteren bu tespitler, e-ders uygulamalarında öğretmen niteliklerinin önemli olduğunu ve öğrencilerin teknoloji temelli uygulamalara yönelik ilgi, memnuniyet ve motivasyonlarıyla doğrudan ilişkili bulunduğunu göstermektedir.

Sonuç olarak, pandemi süreciyle tüm eğitim örgütlerinde e-öğrenme etkinlikleri önem kazanmıştır ve yüz yüze eğitimin yapılamamasından kaynaklanan sınırlılıkları aşmada etkili bir araç olmuştur. Başta yükseköğretim kurumları olamk üzere eğitimin her kademesinde uzaktan eğitim uygulamaları çeşitli internet platformları kanalıyla gerçekleştirilmeye çalışılmıştır. Ancak, uzaktan eğitim uygulamaları ülkeden ülkeye, bir eğitim kurumundan diğer eğitim kurumuna göre farklılıklar göstermektedir. Favale ve diğerleri (2020) pandemiden kaynaklı üniversite kampüslerindeki zorluklarla internet yoluyla başarılı bir şekilde mücadele edilerek bu süreçte üniversitenin faaliyetlerini sürdürebildiğini ifade etmektedir. Diğer taraftan, hızlı bir şekilde uzaktan eğitim platformlarına yapılan geçiş beraberinde e-ders uygulamalarında aksaklıları da getirmiştir. $\mathrm{Bu}$ aksaklıklar e-ders kaynaklarını hazırlamada, uygun içerikler bulmada ve öğretmenlerin çevrim-içi uygulamalarına adaptasyonunda (Zaharah \& Kirilova, 2020) belirgin olarak görülmüştür. Ayrıca, öğrencilerin bu pandemi öncesinde e-öğrenme kullanımına iyi hazırlanmadığını gösteren kanıtlar (Mailizar ve diğerleri, 2020) bulunmaktadır. Bu durum, e-ders uygulamalarının öğrencilerin ilgi, memnuniyet ve motivasyonlarını doğrudan etkilemekte ve uzaktan eğitimin birçok avantajları olmasına karşın öğrencilerin yüz yüze eğitime eğilimlerini güçlendirmektedir.

E-öğrenme süreçlerinde öğrenci memnuniyetinin artırılması için başta öğretmen niteliklerinin geliştirilmesi oldukça önemlidir. Bu bağlamda öğrenci- öğretmen etkileşiminin güçlendirilmesinin yanı sıra e-ders materyallerinin, içeriklerinin, öğrenme ortamı ile öğrenme topluluğunun da hazır edilmesi gerekmektedir. Öğretmenlerin yenilikçilik düzeylerinin geliştirilmesine yönelik eğitim politikalarının öne çıarılması bu noktada önemli olabilir. Eğitim örgütlerinde uzaktan öğrenmeye yönelik öğretmen ve öğrenci adaptasyon sorununu çözmeye, içerik geliştirmeye, e-ders ortamlarının öğrencileri pasif ve edilgen bir öğrenme sürecinden kurtarmaya dönük hizmet içi uygulamalar, destekleyici ve geliştirici etkinlikler artırılmalıdır.

Covid-19 pandemi süreci ve yüz yüze eğitim olanaklarını sınırlayan benzer olaylar tüm dünyada eğitime yönelik bilindikleri değiştirmiş ve değiştirmeye de devam edecek gibi durmaktadır. Geleneksel öğretim yöntem ve tekniklerinin, öğretmen merkezli yaklaşımların e-ders ortamlarına da yansitılması bu kuşak öğrencilerinin ilgi, memnuniyet ve motivasyonlarını düşürdüğü bilinmektedir. İyi hazırlanmış bir e-ders içeriğinin 2000'li yılların kuşağının daha çok ilgisini çekeceği düşünülmektedir. Ancak, her bireyin öğrenme stratejisinin farklılıklar gösterebileceği ve bireyin sosyoekonomik dezevantajlılıklarının öğrenme sürecini olumsuz etkileyebileceği gerçeği de göz ardı edilmemelidir. Bu bağlamda öğrenci memnuniyetini öne çıkaran e-ders uygulamalarının tüm süreçlerinin titizlikle planlanması, hazırlanması ve uygulanması gerekmektedir.

\section{Kapsam ve Sinırlılıklar}

i. $\quad$ Bu araştırma 2019-2020 akademik yılında KKTC'de özel bir üniversitenin fen edebiyat fakültesi ile eğitim fakültesi öğrencileri ile bu öğrencilere sunulan e-dersleri ile sınırlıdır.

ii. $\quad \mathrm{Bu}$ araştırmada özellikle Covid-19 pandemisi sebebiyle farklı üniversitelerdeki e-öğrenme memnuniyeti üzerine daha geniş kapsamlı bir çalışma planlanmasına karşın, veri toplama süreçlerinde karşılaşılabilecek olası zorluklar gözetildiği için örneklem grubu ilgili üniversitenin belirtilen bölümlerini kapsamaktadır. 
Etik Kurul Onayı: Araştırmada kullanılan ölçekler için üniversitenin etik kurulundan olur alınmıştır. Ayrıca, ölçeklerin kullanılabilmesi için ilgili dekanlığın bilgisi ve izni dairesinde ve ölçeği geliştiren yazarların ölçek kullanımına ilişkin izinleri doğrultusunda yapılmıştır.

\section{Kaynakça}

Akar, S. G. M. (2019). Does it matter being innovative: Teachers' technology acceptance. Education and Information Technologies, 24(6), 3415-3432.

Al-Fraihat, D., Joy, M., Masa'deh, R., Sinclair, J. (2020). Evaluating e-learning systems success: an empirical study, Computers in Human Behavior, 102, 67-86. https://doi.org/10.1016/j.chb.2019.08.004

Al, U. ve Madran, O. (2004). Web tabanlı uzaktan eğitim sistemleri: sahip olması gereken özellikler ve standartlar. Bilgi Dünyası, 5(2), 259-271.

Almaiah, M. A. (2018). Acceptance and usage of a mobile information system services in University of Jordan. Education and Information Technologies, 23(5), 1873-1895.

Almaiah, M. A., Al-Khasawneh, A. \& Althunibat, A. (2020). Exploring the critical challenges and factors influencing the E-learning system usage during COVID-19 pandemic, Education and Information Technologies. https://doi.org/10.1007/s10639-020-10219-y

Atasoy, R., Cemaloğlu, N. (2018). Evaluation of Quality Policies on Education in Turkish Education System. Universal Journal of Educational Research, 6(7): 1129 - 1140.

Atasoy, R., \& Güçlü, N. (2019). PIAAC 2015 sonuçlarına göre Türkiye'deki yetişkinlerin sözel okuryazarlık becerilerinin değerlendirilmesi. Hacettepe Üniversitesi Eğitim Fakültesi Dergisi. 35(4), 774-796. https://doi.org/10.16986/HUJE.2019053682.

Atasoy, R. \& Çoban Ö. (2020). Relationship Between Learning Strategies and Socioeconomic Situation, ICT Using Skills, Age, Educational Status, Problem-Solving Skills, International Journal of Education Technology and Scientific Researches, 5(11), 384-422.

Atıcı, B. (2004). Sosyal Bilgi İnşasına Dayalı Sanal Öğrenme Çevrelerinin Öğrenci Başarısı ve Tutumlarına Etkisi, Doktora Tezi. Fırat Üniversitesi Sosyal Bilimler Enstitüsü. Eğitim Bilimleri Anabilim Dalı. Elazı $\breve{g}$.

Bandura, A. (2002). Social cognitive theory in cultural context, Applied Psychology, 51 (2). https://doi.org/10.1111/1464-0597.00092

Bangert, A.W.(2004). The seven principles of good practice: a framework for evaluating online teaching. Internet and Higher Education, 7(3), 217-232.

Berge, Z. L. (2013). Barriers to communication in distance education, Turkish Online Journal of Distance Education, 1(31) http://tojde.anadolu.edu.tr/yonetim/icerik/makaleler/866published.pdf

Bertiz, Y. (2017). Çevrimiçi sosyal eğitim platformlarının kullanılabilirliklerinin değerlendirilmesi: Eğitim bilişim ağı (EBA) sistemi örneği. Science, Education, Art and Technology Journal (SEAT Journal), 1(2), 63-76.

Bozkurt, A. (2020). Koronavirüs (Covid-19) pandemi süreci ve pandemi sonrası dünyada eğitime yönelik değerlendirmeler: Yeni normal ve yeni eğitim paradigması. AUAd, 6(3), 112-142.

Brophy, J. (2010). Motivating students to learn (3rd ed.). Routledge. 
Büyüköztürk, Ş., Çakmak, E.K., Akgün, Ö.E, Karadeniz, Ş ve Demirel, F. (2016). Bilimsel araştırma yöntemleri. Pegem Akademi.

Celen, F., Celik, A., \& Seferoglu, S. (2018). Yükseköğretimde Çevrim-içi Öğrenme: Sistemde Yaşanan Sorunlar ve Çözüm Önerileri. Journal Of European Education, 1(1), 25-34.

Carolan, C., Davies, C.L., Crookes, P., McGhee, S. \& Roxburgh, M. (2020). COVID 19: Disruptive impacts and transformative opportunities in undergraduate nurse education, Nurse Educ Pract, 46(102807). https://doi.org/10.1016/j.nepr.2020.102807

Chaney B.H., Eddy, J.M., Dorman, S.M., Glessner, L., Lee Green, B. \& Lara-Alecio, R. (2007) Development of an instrument to assess student opinions of the quality of distance education courses, American Journal of Distance Education, 21(3), 145-164.

Cheng, Y. M. (2012). Effects of quality antecedents on e-learning acceptance. Internet Research, 22(3), 361-390. https://www.emerald.com/insight/content/

Cidral, W. A., Oliveira, T., Di Felice, M., \& Aparicio, M. (2018). E-learning success determinants: Brazilian empirical study. Computers and Education, 122, 273-290. https://doi.org/10.1016/j.compedu.2017.12.001

Clark, R. C., \& Mayer, R. E. (2016). E-learning and the science of instruction: Proven guidelines for consumers and designers of multimedia learning. John Wiley \& Sons.

Dahlstrom, E., Brooks, D. C., \& Bichsel, J. (2014). The current ecosystem of learning management systems in higher education: Student, faculty, and IT perspectives research report. Louisville, CO: ECAR.

Dai, D. \& Xia, X. (2020). Whether the school self-developed e-learning platform is more conducive to learning during the covid-19 pandemic?, Best Evid Chin Edu, 5(1), 569-580. https://doi.org/10.15354/bece.20.ar030.

Deci, E. L. and R. M. Ryan (1985). Intrinsic Motivation and Self-Determination in Human Behavior, Plenum.

Demirel, Ö. (2015). Eğitimde program geliştirme kuramdan uygulamaya, Pegem Akademi Yayınları.

De Muth, J. E. (2014). Basic statistics and pharmaceutical statistical applications. Chapman and Hall/CRC.

Dinçer, S., \& Yeşilpınar-Uyar, M. (2016). E-Öğrenme sistemlerinin kullanımı sürecinde karş1laşılan sınıf yönetimi ile ilişkili sorunlar ve çözüm önerileri. Kuram ve Uygulamada Egitim Yönetimi Dergisi, 21(4), 453-470.

Ebner, M., Schön, S., Braun, C., Ebner, M., Grigoriadis, Y., Haas, M., Leitner, P., \& Taraghi, B. (2020). COVID-19 epidemic as e-learning boost? Chronological development and effects at an Austrian university against the background of the concept of "e-learning readiness", Future Internet, 12(6), 73-94; https://doi.org/10.3390/fi12060094

El-Seoud, S.A., El-Khouly, M. A., \& Taj-Eddin, I.A.T.F. (2016). Motivation in e-learning: How do we keep learners motivated in an e-Learning environment?, International Journal of Learning and Teaching, 2(1), 63-66, https://doi.org/10.18178/ijlt.2.1.63-66

European Commission (2013), Survey of Schools: ICT in Education, Publications Office of the European Union 
Covid-19 Pandemi Sürecinde Yapılan E-Ders Uygulamalarının Etkililiğinin Öğrencilerin...

Favale, T., Soro, F., Trevisan, M., Drago, I., Mellia, M. (2020). Campus traffic and e-Learning during COVID-19 pandemic, Computer Networks, 176(107290). https://doi.org/10.1016/j.comnet.2020.107290

Field, A. (2013). Discovering statistics using IBM SPSS statistics. Sage.

Genç, M. F., Gümrükçüoğlu, S. (2020). Koronavirüs (Covid-19) sürecinde ilâhiyat fakültesi öğrencilerinin uzaktan eğitime bakışları. Turkish Studies, 15(4), 403-422. https://dx.doi.org/10.7827/TurkishStudies.43798

Ghazal, S., Al-Samarraie, H., \& Aldowah, H. (2018). "I am Still Learning”: Modeling LMS critical success factors for promoting students' experience and satisfaction in a blended learning environment. IEEE Access, 6(6), 77179-77201. https://doi.org/10.1109/ACCESS.2018.2879677

Haghshenas, M. (2019). A model for utilizing social Softwares in learning management system of E-learning. Quarterly Journal of Iranian Distance Education, 1(4), 25-38.

Hair, J. F., Black, W. C., Babin, B. J., Anderson, R. E., \& Tatham, R. L. (2013). Multivariate Data Analysis. Pearson Education Limited.

Halili, S. H. (2019). Technological advancements in education 4.0. The Online Journal of Distance Education and E-Learning, 7(1), 63-69.

Hara, N., \& Kling, R. (2003). Students' distress with a web-based distance education course: An ethnographic study of participants' experiences. Turkish Online Journal of Distance Education, 4(2). https://pdfs.semanticscholar.org/

Harandi, S. R. (2015). Effects of e-learning on students' motivation, Social and Behavioral Sciences, 181, 423 - 430. https://doi.org/10.1016/j.sbspro.2015.04.905

Hassanzadeh, A., Kanaani, F., \& Elahi, S. (2012). A model for measuring e-learning systems success in universities. Expert Systems with Applications, 39(12), 10959-10966. https://doi.org/10.1016/j.eswa.2012.03.028

Hochberg, J., \& Tamhane, A. C. (1987). Multiple comparison procedures. (No. 519.535 H655m Ej. 1). John Wiley \& Sons.

Islam, N., Beer, M., \& Slack, F., (2015). E-learning challenges faced by academics in higher education. Journal of Education and Training Studies, 3(5), 102-112, Available online: http://shura.shu.ac.uk/10403/ .

John, Keller \& Katsuaki Suzuki (2004) Learner motivation and E-learning design: A multinationally validated process, Journal of Educational Media, 29(3), 229-239.

Karabay, E. (2013). Aile ve okul özelliklerinin PISA okuma becerileri, matematik ve fen okuryazarlığını yordama gücünün yıllara göre incelenmesi, (Yüksek Lisans Tezi, Gazi Üniversitesi). tez.yok.gov.tr.

Karabay, E., Yıldırım, A., \& Güler, G. (2015). Yıllara göre PISA matematik okuryazarlığının öğrenci ve okul özellikleri ile ilişkisinin aşamalı doğrusal modelleri ile analizi, Mehmet Akif Ersoy Üniversitesi Eğitim Fakültesi Dergisi, 1(36), 137-151.

Karahan, E. \& Bozan, M. A. \& Akçay, A. O. (2020). Sınıf öğretmenliği lisans öğrencilerinin pandemi sürecindeki çevrim içi öğrenme deneyimlerinin incelenmesi, Turkish Studies, 15(4), 201-214. https://dx.doi.org/10.7827/TurkishStudies.44348

Keller, J. M. (2008). First principles of motivation to learn and e-learning. Distance Education, 29(2), 175-185. https://doi.org/10.1080/01587910802154970 
Kim, K., Trimi, S., Park, H., \& Rhee, S. (2012). The impact of CMS quality on the outcomes of elearning systems in higher education: An empirical study. Decision Sciences Journal of Innovative Education, 10(4), 575-587. https://doi.org/10.1111/j.1540-4609.2012.00360.x

Kim, K.-J., \& Frick, T. W. (2011). Changes in Student Motivation During Online Learning. Journal of Educational Computing Research,44(1), 123. https://doi.org/10.2190/EC.44.1.a

King, E. \& Boyatt, R. (2015). Exploring factors that influence adoption of e-learning within higher education. British Journal of Educational Technology. 46(6), 1272-1280.

Kolburan Geçer, A., \& Topal Deveci, A., (2015). E-derslere yönelik memnuniyet ölçeğinin geliştirilmesi:geçerlik ve güvenirlik çalışması, Eğitimde Kuram ve Uygulama, 11(4), 12721287 https://toad.halileksi.net/olcek/e-derslere-yonelik-memnuniyet-olcegi

Lee, Y. H., Hsieh, Y. C., \& Hsu, C. N. (2011). Adding innovation diffusion theory to the technology acceptance model: Supporting employees' intentions to use e-learning systems. Journal of Educational Technology \& Society, 14(4), 124-137.

Lin, H.M., Chen, W.J. \& Nien, S.F. (2014). The study of achievement and motivation by elearning-a case study, International Journal of Information and Education Technology, 4(5), 421-425.

Liu, J. (2013). The assessment agent system: Design, development, and evaluation. Educational Technology Research and Development, 60(2), 197-215.

Lwoga, E. (2014). Critical success factors for adoption of web-based learning management systems in Tanzania. International Journal of Education and Development using ICT, 10(1).

Mailizar, Almanthari, A., Maulina, S., \& Bruce, S. (2020). Secondary school mathematics teachers' views on e-learning 1mplementation barriers during the COVID-19 Pandemic: The case of Indonesia. Eurasia Journal of Mathematics, Science and Technology Education, 16(7), em1860. https://doi.org/10.29333/ejmste/8240

Manuela, P., \& Brigitte, M. (2010), Online or face-to-face? Students' experiences and preferences in e-learning, The Internet and Higher Education, 13(4), 292-297. https://doi.org/10.1016/j.iheduc.2010.09.004

Margarida, R., \& Federico, B. (2017). Digital technologies and learning outcomes of students from low socio-economic background: An Analysis of PISA 2015, Publications Office of the European Union, doi:10.2760/415251

McCutcheon, K., Lohan, M., Traynor, M., \& Martin, D.A. (2015). Systematic review evaluating the impact of online or blended learning vs. face-to-face learning of clinical skills in undergraduate nurse education. $J \quad A d v \quad$ Nurs. 71(2):255-270. https://doi.org/10.1111/jan.12509

McKillup, S. (2012). Statistics explained: An introductory guide for life scientists (Second edition). United States: Cambridge University Press.

MEB (2020). MEB güncel haberler. "Eba, 1.2 milyar tıklanma sayıslyla kendi rekorunu güncelledi”, https://www.meb.gov.tr

Mtebe, J. S., \& Raphael, C. (2018). Key factors in learners' satisfaction with the e-learning system at the University of Dar es Salaam, Tanzania. Australasian Journal of Educational Technology, 34(4).

Muilenburg, L.Y. \& Berge, Z. L. (2005). Student barriers to online learning: A factor analytic study, Distance Education, 26:1, 29-48. https://doi.org/10.1080/01587910500081269 
Özer, Y., \& Anıl, D. (2011). Öğrencilerin fen ve matematik başarılarını etkileyen faktörlerin yapısal eşitlik modeli ile incelenmesi, Hacettepe Üniversitesi Eğitim Fakültesi Dergisi, 41(41), 313-324.

Paris, S. G., \& Turner, J. C. (1994). Situated motivation. In P. R. Pintrich, D. R. Brown \& C. E. Weinstein (Eds.), Student motivation, cognition, and learning: Essays in honor of Wilbert J. McKeachie (pp. 213-237). Lawrence Erlbaum.

Paulus, T., \& Scherff, L. (2008). "Can anyone offer any words of encouragement?" Online dialogue as a support mechanism for preservice teachers. Journal of Technology and Teacher Education, 16(1), 113-136. https://www.learntechlib.org/primary/p/22883/.

Pei, L., \& Wu, H. (2019). Does online learning work better than offline learning in undergraduate medical education? A systematic review and meta-analysis. Med Educ Online, 24(1):1666538. https://doi.org/10.1080/10872981.2019.1666538

Pirnary-Dummer, P., Ifenthaler, D., \& Spector, J. M. (2010). Highly integrated model assessment technology and tools. Educational Technology Research and Development, 58(1), 3-18.

Rose, R. M., \& Blomeyer, R. L. (2007). Research Committee Issues Brief. Access and Equity in Online Classes and Virtual Schools. North American Council for Higher Learning. http://files.eric.ed.gov/fulltext/ED509623.pdf

Roskvist, R., Eggleton, K., \& Goodyear-Smith, F. (2020). Provision of e-learning programmes to replace undergraduate medical students' clinical general practice attachments during COVID-19 stand-down, Education for Primary Care. https://doi.org/10.1080/14739879.2020.1772123

Ryan, R. M., \& Deci, E. L. (2000). Self-determination theory and the facilitation of intrinsic motivation, social development, and well-being. American Psychologist, 55(1), 68-78. https://doi.org/10.1037/0003-066X.55.1.68

Sezgin S., (2020). Kitlesel açık çevrimiçi derslerin öğretmen eğitimindeki rolleri: Bilgisayar ve öğretim teknolojileri öğretmen adaylarının programlamaya yönelik kitlesel açık çevrimiçi ders deneyimlerinin incelenmesi. Yüksekögretim ve Bilim Dergisi/Journal of Higher Education and Science, 10(1), 166-177. https://doi.org/10.5961/jhes.2020.378

Shroff, R. H., \& Vogel, D. R. (2009). Assessing the factors deemed to support individual student intrinsic motivation in technology supported online and face-to-face discussions. Journal of Information Technology Education, 8, 59-85. https://doi.org/10.28945/160

Stevens, J. P. (2009). Applied multivariate statistics for the social sciences (Fifth edition). Taylor and Francis Group, LLC.

Suanpang, P., Petocz, P., \& Kalceff, W. (2004). Student attitudes to learning business statistics: Comparison of online and traditional methods. Journal of Educational Technology \& Society, 7(3), 9-20.

Sun, P. C., Tsai, R. J., Finger, G., Chen, Y. Y., \& Yeh, D. (2008). What drives a successful eLearning? An empirical investigation of the critical factors influencing learner satisfaction. Computers \& education, 50(4), 1183-1202.

Sun, P. C., Tsai, R. J., Finger, G., Chen, Y. Y., \& Yeh, D. (2008). What drives a successful elearning? An empirical investigation of the critical factors influencing learner satisfaction. $\begin{array}{llll}\text { Computers and Education, } & \text { 50(4), }\end{array}$ https://doi.org/10.1016/j.compedu.2006.11.007 
Sweets, R. ve Meates, A. (2004). ICT and Low Achievers: What Does PISA Tell Us? In A. Karpati, Promoting Equity through ICT in Education: Projects, Problems, Prospects. Budapest: Hungarian Ministry of Education and OECD.

Tabachnick, B. G., \& Fidell, L. S. (2013). Using multivariate statistics (Sixth edition). Pearson Education.

Teo, T. S., Kim, S. L., \& Jiang, L. (2020). E-learning implementation in south Korea: Integrating Effectiveness and Legitimacy Perspectives. Information Systems Frontiers, 22(2), 511-528.

The Ministry of Education of China. (2016) The Ministry of Education of China no-tice on printing and distributing the "Thir-teenth Five-Year Plan for Educational Informatization".

Torun, N. K., \& Cengiz, E. (2019). Endüstri 4.0 bakış açısının öğrenciler gözünden teknoloji kabul modeli (TKM) ile ölçümü. Uluslararası Íktisadi ve İdari İncelemeler Dergisi, (22), 235250.

Turan, A. H., \& Çolakoğlu, B. E. (2008). Facultys acceptance and use of technology in higher education: An empirical assessment at Adnan Menderes University. Doğuş Üniversitesi Dergisi, 9(1), 106-121.

Warschauer, M., \& Matuchniak, T. (2010). New technology and digital worlds: Analyzing evidence of equity in access, use, and outcomes, Review of Research in Education, 34(1), 179-225. https://doi.org/10.3102/0091732X09349791

Wojciechowski, A., \& Palmer, L. B. (2005). Individual student characteristics: Can any be predictors of success in online classes? Online Journal of Distance Learning Administration, 8(2), 1-20.

Young, S. (2006). Student views of effective online teaching in higher education. The American Journal of Distance Education, Lawrence Erlbaum Associates, 65-77.

Zaharah, Z., \& Kirilova, G. I. (2020). Impact of corona virus outbreak towards teaching and learning activities in Indonesia. SALAM: Jurnal Sosial dan Budaya Syar-i, 7(3). https://doi.org/10.15408/ sjsbs.v7i3.15104 